\title{
WATER FOR SANTA CRUZ COUNTY: NONPROFIT ADVOCACY AND PUBLIC POLICY
}

\author{
A Professional Project Report \\ presented to \\ the Faculty of California Polytechnic State University, \\ San Luis Obispo
}

\begin{abstract}
In Partial Fulfillment
of the Requirement for the Degree

Master of City and Regional Planning
\end{abstract}

by

Matthew Alexander Orbach

June 2014 
(C) 2014

Matthew Alexander Orbach

ALL RIGHTS RESERVED 


\section{COMMITTEE MEMBERSHIP}

TITLE: $\quad$ Water for Santa Cruz County: Nonprofit Advocacy and Public Policy

AUTHOR: $\quad$ Matthew Alexander Orbach

DATE SUBMITTED: June 2014

COMMITTEE CHAIR: $\quad$ Chris W. Clark, J.D.

Lecturer of City and Regional Planning

COMMITTEE MEMBER: W. David Conn, D. Phil.

Professor of City and Regional Planning

COMMITTEE MEMBER: Michael E. Rotkin, Ph.D.

Lecturer and Director of Field Studies in Community Studies, University of California, Santa Cruz (Retired) 


\begin{abstract}
Water for Santa Cruz County: Nonprofit Advocacy and Public Policy Matthew Alexander Orbach
\end{abstract}

This professional Masters project involved turning the Sustainable Water Coalition (SWC), an unincorporated group of Santa Cruz residents advocating the work of the two local water agencies, into a California Nonprofit Corporation and an IRS recognized 501(c)(4) social welfare organization. This paper examines the biophysical, human, and institutional systems surrounding water use in Santa Cruz County, California, and the roles that a nonprofit advocacy organization can play within that framework. These roles are illustrated through an exploration of citizen involvement and advocacy in the comparative cases of the scwd $d^{2}$ Desalination Program in Santa Cruz, California, and a proposed wastewater treatment facility in Los Osos, California. The paper also describes the step-by-step process of turning SWC into a California Nonprofit Corporation and IRS recognized 501(c)(4) social welfare organization as a response to the need for a nonprofit advocacy group supporting the work of the City of Santa Cruz Water Department (City) and the Soquel Creek Water District (District). The goals of SWC, the City, and the District include: promoting water conservation; protecting local surface water resources; maintaining riparian habitats for endangered species; resting and recharging overdrafted coastal aquifers to avoid seawater intrusion; and attaining a supplemental water supply to make the community more resilient in times of drought. 


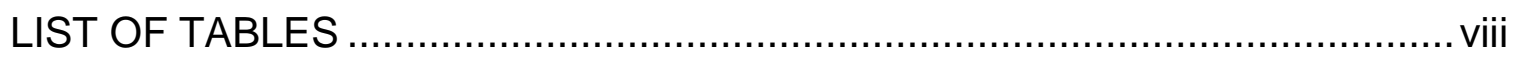

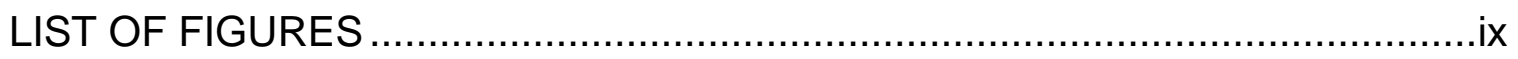

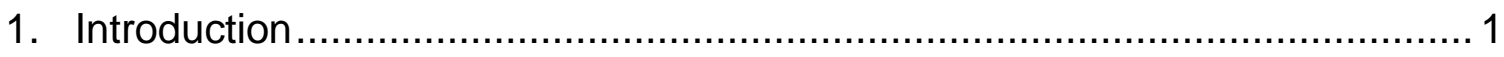

2. History of Water Use in Santa Cruz County.............................................. 3

Early History of Water Use in the Santa Cruz Area ..................................... 3

History of Water Suppliers in the Santa Cruz Area ..................................... 3

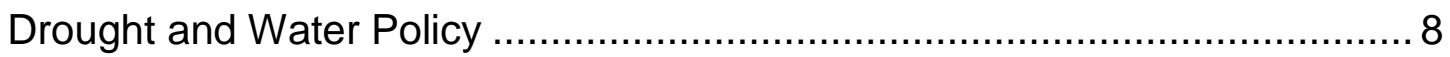

scwd2 Desalination Program............................................................... 11

Challenges to Desalination.................................................................. 12

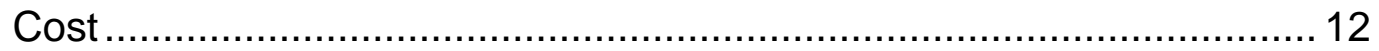

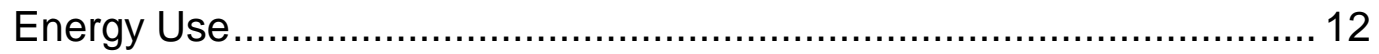

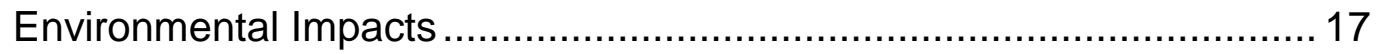

3. Current Political Climate in Santa Cruz County ....................................... 20

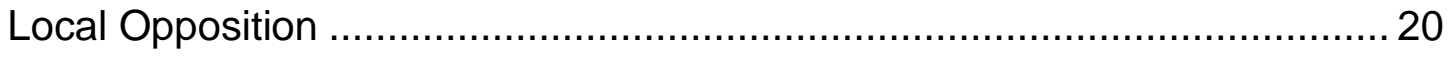

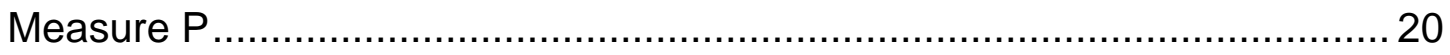

What Measure P Means....................................................................... 23

Public Comment Period for the scwd2 Draft Environmental Impact Report .. 24

Public Comments on the Draft Environmental Impact Report ................ 26

Current Status of scwd2 Draft Environmental Impact Report....................... 26

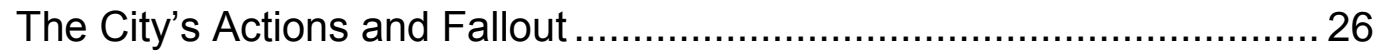

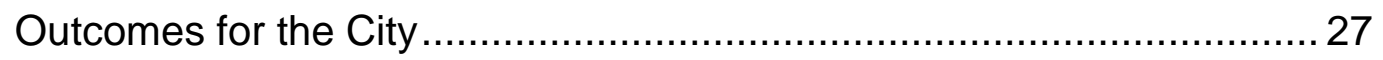

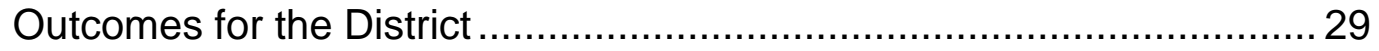

4. Rationale for Creating an Advocacy Organization ...................................... 31

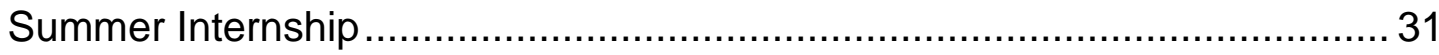

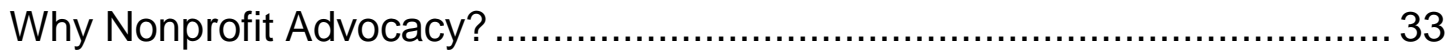

Case Study - Los Osos Community Services District.................................. 35

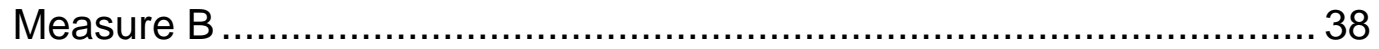

Taxpayers Watch v. Los Osos Community Services District ................. 40

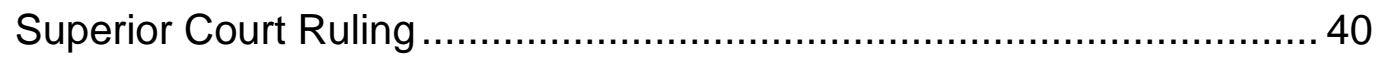

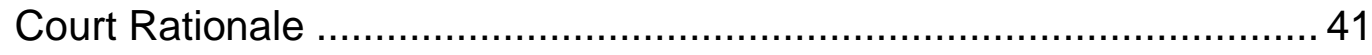

Measure B and Measure P ............................................................. 42 
5. Starting a Nonprofit Advocacy Group ..................................................... 46

SeeWaterSC vs. Sustainable Water Coalition............................................ 46

Presentation to Sustainable Water Coalition ................................................. 47

What the Sustainable Water Coalition Is and Is Not................................... 48

501(c)(3), 501(c)(4), or Nonprofit Unincorporated Association..................... 49

Organizational Documents and Structure .................................................... 51

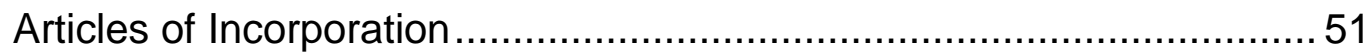

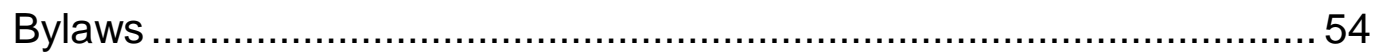

Employer Identification Number (EIN) …........................................... 55

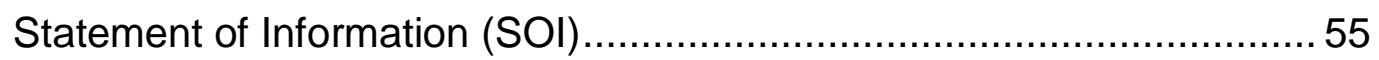

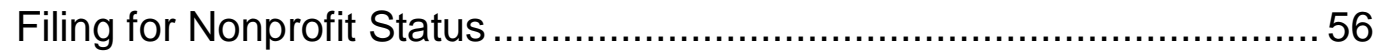

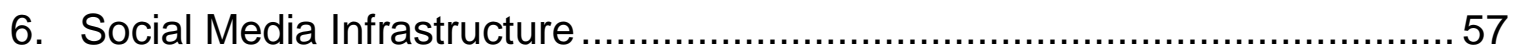

Facebook Demographics and 'Promoting' - Knowing Your Constituents ..... 57

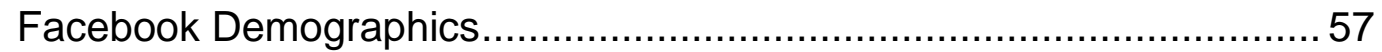

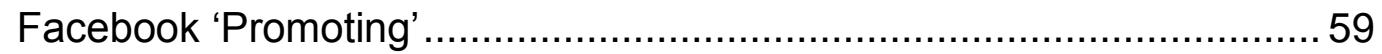

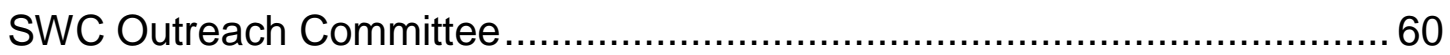

January 18th, 2014 SWC Outreach Committee Meeting ........................ 60

March 1st, 2014 SWC Outreach Committee Meeting ............................. 62

April 8th, 2014, the SWC Email List, and a Domain Name ..................... 63

Current Status of SWC Outreach Committee Work............................... 65

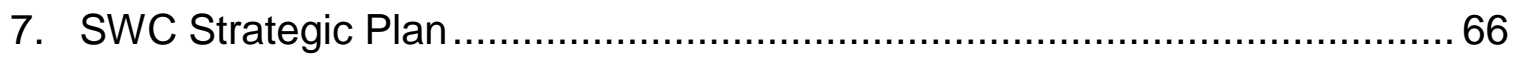

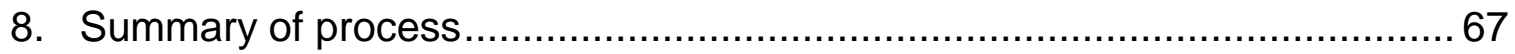

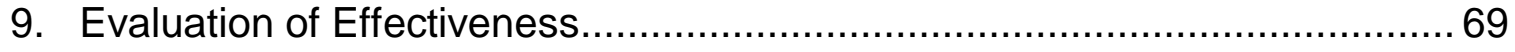

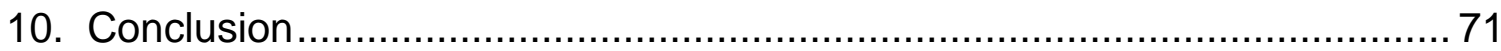

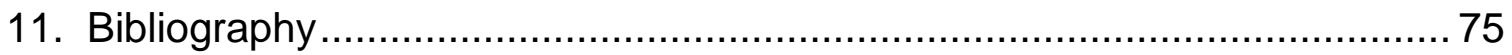

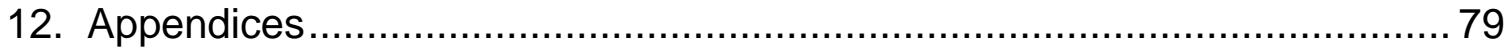

Appendix A: Presentation to Sustainable Water Coalition .............................. 79

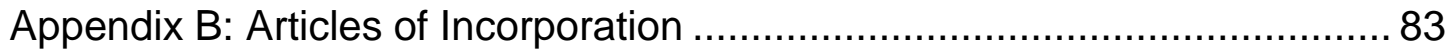

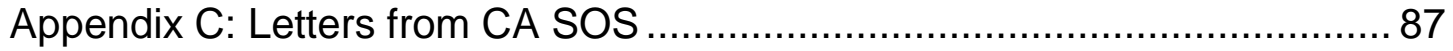

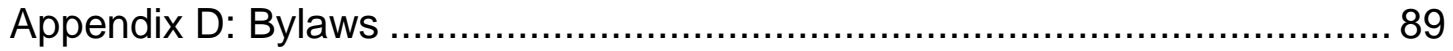

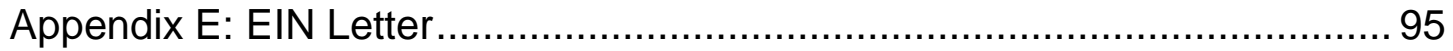

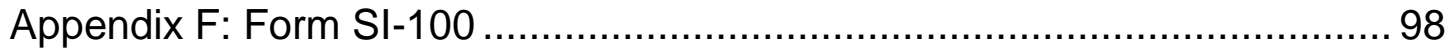

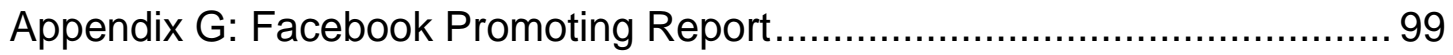

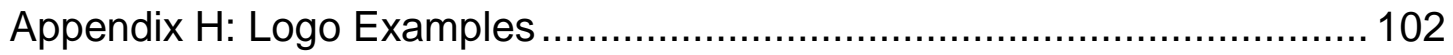


Appendix I: Official Stratus Email and Stratus Email for Facebook ............ 103

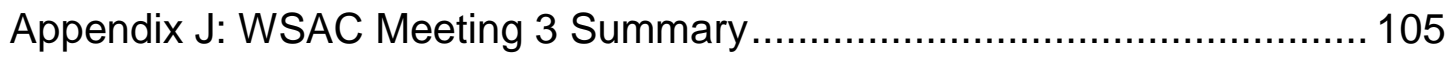

Appendix K: "Santa Cruz puts brakes on desal", Santa Cruz Sentinel........ 111

Appendix L: SWC Meeting Notes, 5-19-14 ........................................... 113 


\section{LIST OF TABLES}

$\underline{\text { Table }}$

Page

Table $1-$ scwd $^{2}$ ETWG Selected Projects and Programs ................................ 16

Table 2 - Organizational Structure Choice Matrix .............................................. 49 


\section{LIST OF FIGURES}

Figure

Page

Figure 1 - City of Santa Cruz Municipal Utilities Service Area ............................ 5

Figure 2 - City of Santa Cruz Organization Chart ........................................... 6

Figure 3 - Soquel Creek Water District Service Area...................................... 8

Figure 4 - Santa Cruz Sentinel, August 19th, 2013 ...................................... 26

Figure 5 - SWC Facebook Page Demographics on 1/21/14 .......................... 58

Figure 6 - SWC Facebook Page Demographics on 5/12/14 _........................... 58 


\section{Introduction}

The issue of water use in Santa Cruz County has been a contentious topic for almost forty years. Now, due to a combination of overdrafted aquifers, increased in-stream flow requirements for endangered salmon and steelhead populations, drought, and local opposition to the actions of the City of Santa Cruz Water Department (City) and the Soquel Creek Water District (District), this issue has reached a boiling point. Several local groups feel that the alternatives covered in the California Environmental Quality Act (CEQA) process that the City and District engaged in, the process that led them to their 'preferred option' of desalination, were not adequate. While these groups represent only a small portion of the population served by these two water districts, they have been successful in taking control of the political process, capitalizing on low public participation in local elections and the fact that the government agencies involved are extremely limited as far as the activities in which they can engage to share information about the work they have been doing and to promote the 'preferred option' to which their work has led them. The goal of this professional Masters project was to turn the Sustainable Water Coalition, an existing informal group of concerned citizens advocating the work of the local water agencies, into a California Nonprofit Corporation and 501(c)(4) social welfare organization that can serve to correct this imbalance by educating the general public about: 
- The work of the City and District to increase conservation, offset the impact of current and future growth on water supplies, and identify a sustainable supplemental water supply;

- The alternatives that were considered in the Draft Environmental Impact Report (EIR) for the proposed desalination plant and any others that might be recommended by the Water Supply Advisory Committee (WSAC);

- The thorough public review process that was, and still is, being undertaken;

- The environmental, social, and environmental costs of possible solutions as well as delay and inaction; and

- How, as a result of Measure $P$, the power to decide their fate might be in their own hands.

In doing so, the Sustainable Water Coalition can give all of the citizens of Santa Cruz, including the interests of the currently silent majority of water customers, a better chance of being represented in the political process. 


\section{History of Water Use in Santa Cruz County}

\section{Early History of Water Use in the Santa Cruz Area}

For Santa Cruz, the beginning of water supply development took place in 1792 when the Padres of the Mission Santa Cruz directed the Mission's Indian residents to dig a ditch from the natural springs near the present University of Santa Cruz entrance to the Mission site. That ditch and the adjacent path became High Street. Especially useful during the summer months, this small aqueduct enabled the Padres to occupy a location of superiority above the village and yet not be burdened with the labor of gathering water from the river a hundred feet below. (Santa Cruz City Water Department 2012)

Since that time, water resource management in the Santa Cruz area has grown into an intricate system of reservoirs, wells, water treatment plants, and pipelines that are maintained and operated by the Santa Cruz Water Department (City) and the Soquel Creek Water District (District), providing water services to a community of around 128,000 people.

\section{History of Water Suppliers in the Santa Cruz Area}

In the City of Santa Cruz, water resource management was initially handled by a handful of small private water companies, taking water from freshets, wells, the San Lorenzo River, and other local sources and selling it to the general public. It continued this way until the City of Santa Cruz purchased the Santa Cruz Water Company and the rights to Laguna Creek and consolidated the production from those sources in 1916. Over the next half century, the City sold bonds to purchase other small private water companies and land for reservoirs as well as for the construction of infrastructure related to Newell Creek Dam, Loch Lomond 
Reservoir, Graham Hill Water Treatment Plant, Zayante Dam, Zayante Reservoir, Felton Diversion Station, and Bay Street Reservoir. This infrastructure, completed by the 1970's, is managed by the Santa Cruz Water Department and provides the majority of the surface water supply still used today. With the addition of several groundwater sources, these make up the entire water supply for the 90,000 customers of the Santa Cruz Water Department (Santa Cruz City Water Department, 2012). The City of Santa Cruz Municipal Utilities Service Area is shown in Figure 1. 
Figure 1 - City of Santa Cruz Municipal Utilities Service Area

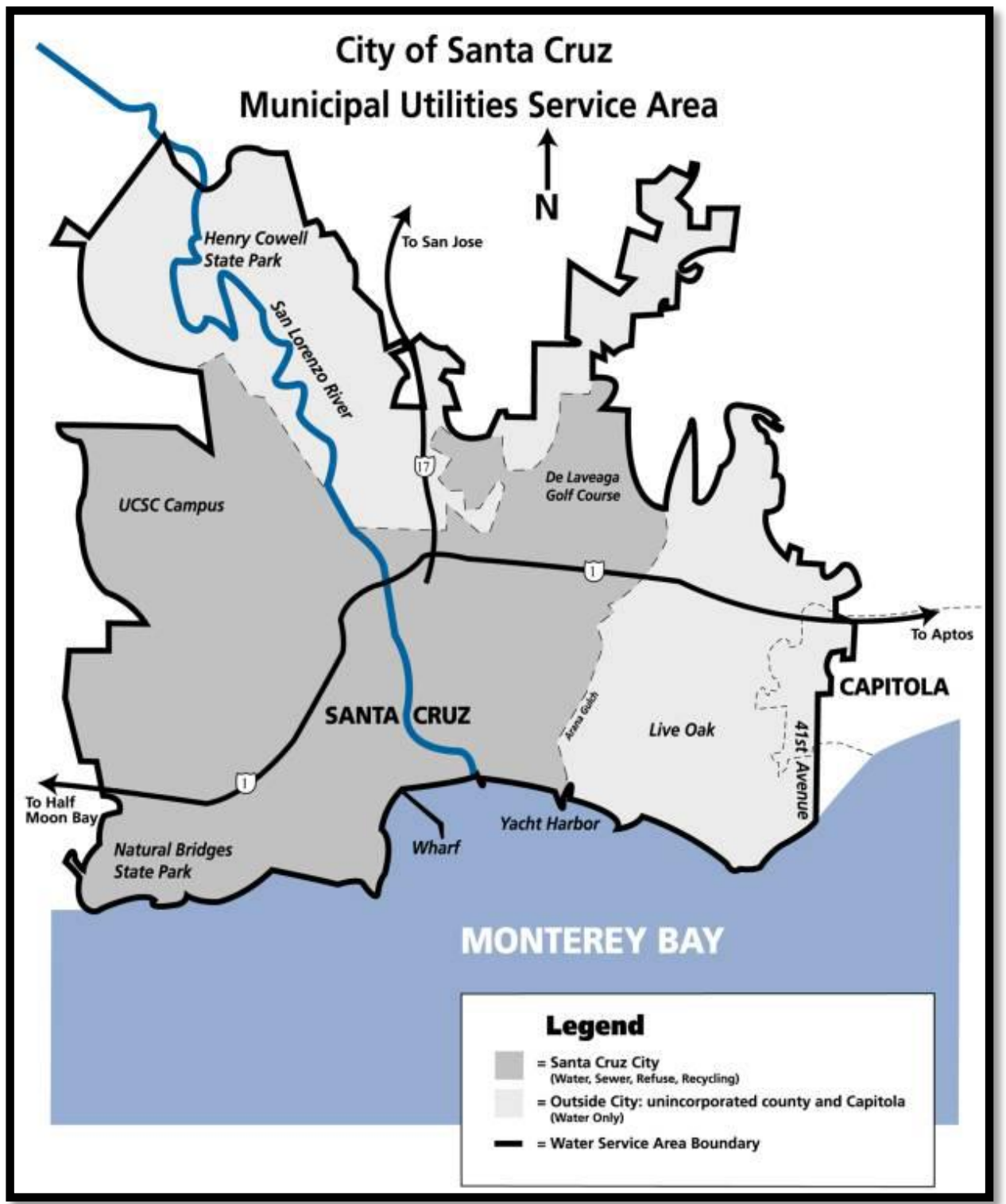

Water management in Santa Cruz is part of the political process. The mission of the Santa Cruz Water Department is "to ensure public health and safety by providing a clean, safe, reliable supply of water" (City of Santa Cruz, 2009b). The department is in charge of day to day operation of the City's water systems, monitoring quality and quantity, maintaining infrastructure, running the water 
conservation program, and many other duties, but they do not make executive decisions about water issues in the City. They provide technical information and analysis to the Water Commission and the City Council regarding water issues. The City of Santa Cruz Organization Chart in Figure 2 illustrates where they reside in the political hierarchy.

Figure 2 - City of Santa Cruz Organization Chart

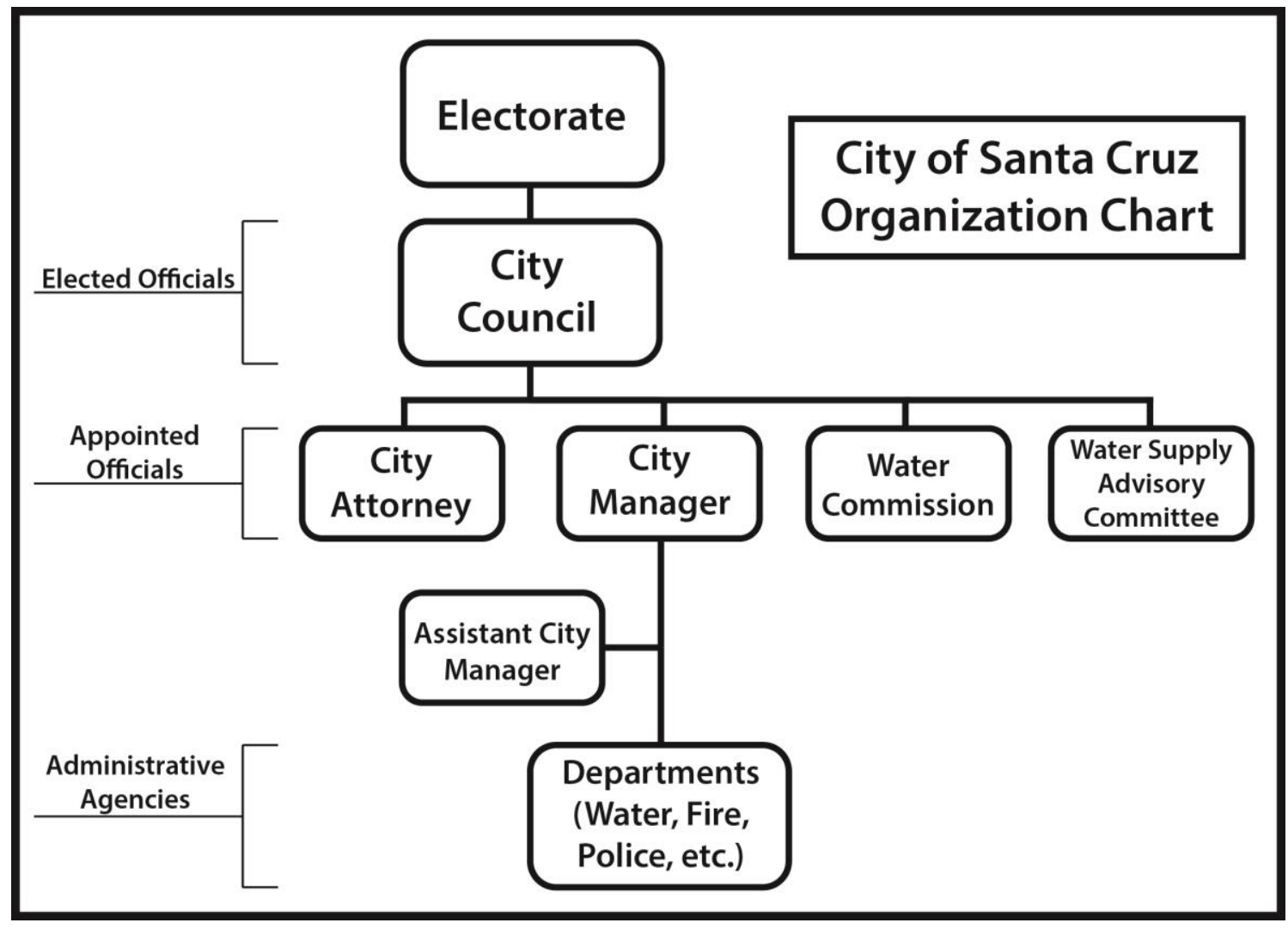

The Soquel Creek Water District (District) was established in 1961 under the name "Soquel Creek County Water District," with the purpose of providing "flood control and water conservation services." In 1964 they purchased the Monterey Bay Water Company, discontinued flood control, and shifted to water resource 
management and conservation services. The District gets one hundred percent of its water from two local aquifers: the Purisima Aquifer, which supplies twothirds of the water for the cities of Capitola, Aptos, and Soquel; and the Aromas Red Sands Aquifer, which supplies the other third for the communities of Seascape, La Selva Beach, and Rio del Mar. In 1983, they dropped the word 'County' from their name and became the Soquel Creek Water District (Soquel Creek Water District, 2008). It is now a nonprofit local government agency that provides water services to 38,000 customers. The Soquel Creek Water District Service Area is shown in Figure 3. 
Figure 3 - Soquel Creek Water District Service Area

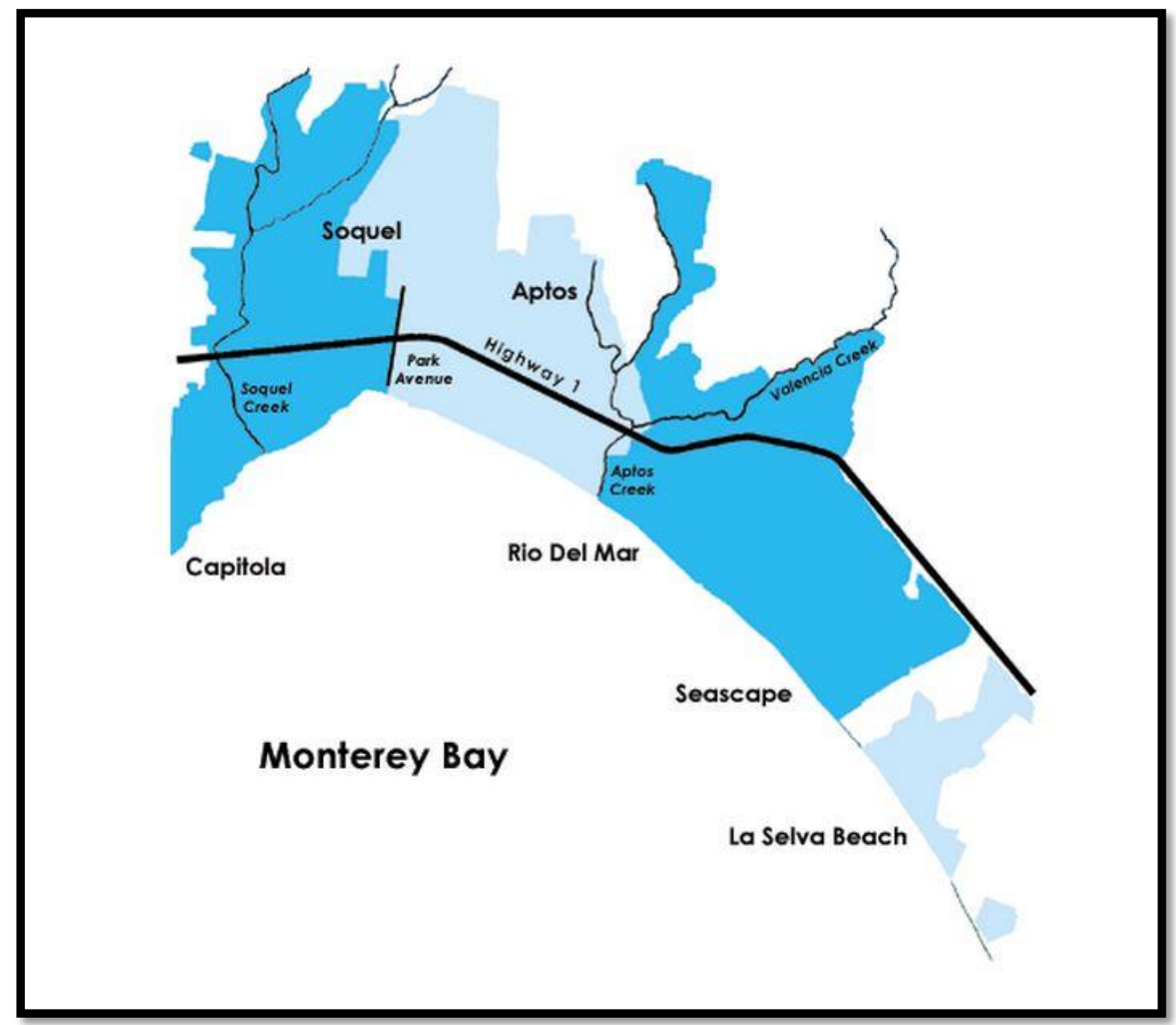

\section{Drought and Water Policy}

Due to water shortages during the droughts of the mid-1970's, water supplies were pushed to the limit and districts began to compete for the same water sources. Because of what they perceived to be an impending water crisis, people recognized that water was a limited resource and that they would benefit from cooperative management. In addition, they acknowledged the relationship between growth management and this limited resource and took steps to create policy that reflected this. 
In 1978, Santa Cruz County adopted a growth management policy ordinance which, among other things, required that the Board of Supervisors each year set a maximum growth rate for the year to come. The ordinance also required that future growth be directed into well-defined urban areas. In 1979, the City of Santa Cruz also adopted a growth management ordinance. In 1980 and 1982, the County adopted an updated General Plan and Local Coastal Plan, respectively. These land use plans, policies, and ordinances, adopted by the two major land use agencies in North Santa Cruz County, had the potential of affecting population trends in ways unforeseen by previous land use and water planning documents. (Santa Cruz City Water Department, 2012)

The drought of the mid-1970's also prompted the search for a supplemental water supply that continues today. Between 1985 and the present there has been in-depth exploration of other local water sources, groundwater assessments, and studies on potential dam sites for potential supplemental water supplies that has not identified other feasible sources of surface or ground water. "In 1997, the City initiated a new effort using a broader based approach known as Integrated Water Planning to consider all practical options for decreasing demand and increasing supply" (City of Santa Cruz, 2010, p. 2). They conducted studies on and assessments of demand, conservation, curtailment, and alternative water supplies at the city and regional level, and then produced an Integrated Water Plan (IWP) with two main goals: reducing "near-term drought 
shortages"; and providing "a reliable supply that meets long-term needs while ensuring protection of public health and safety" (City of Santa Cruz, 2010, p. 3).

Several water resource strategies were evaluated, including system upgrades, additional groundwater, seawater desalination, and curtailment. The final IWP plan, adopted by the City Council on November 8, 2005, identified three main components vital to future water resource management:

1. Reduce average demand through water conservation in all years;

2. Curtailment of water use by up to 15 percent in times of drought; and

3. Additional water supply in the form of a $2.5 \mathrm{mgd}$ seawater desalination facility that would be expandable in $1.0 \mathrm{mgd}$ increments up to $4.5 \mathrm{mgd}$, if needed, in future years" (City of Santa Cruz, 2010, p. 3).

This led to the formation of the scwd ${ }^{2}$ Desalination Program in 2007, which is a joint venture between the City and District designed "to conserve, protect, and create reliable water resources," and "address their different needs and share the costs associated with evaluating the proposed project" (scwd ${ }^{2}$ Desalination Program, 2008). 


\section{scwd2 Desalination Program}

The proposed scwd² Seawater Desalination Project, as the product of a partnership between two water districts with different needs, provided multiple options for utilization. For Santa Cruz, the plant would only be used during extended droughts to meet its water needs and to protect endangered species in streams that would be affected by removing more surface water. Soquel Creek Water District would use the water supply on a regular basis (with the plant running at approximately $1 \mathrm{mgd}$ of the $2.5 \mathrm{mgd}$ capacity) in order to reduce its current level of groundwater extraction and allow groundwater levels to recover (City of Santa Cruz, 2010). The scwd ${ }^{2}$ Seawater Reverse Osmosis Desalination Pilot Test Program was conducted between 2008 and 2009, which involved building a $1 / 10$ scale pilot desalination facility to test and demonstrate the technology for policymakers and the public, and the final $s c w d^{2}$ Seawater Reverse Osmosis Desalination Pilot Test Program Report was released in April 2010. Several other studies were done on intake technology, intake location, brine disposal, and ocean outfall options, and reports were released in 2011. Community meetings were held throughout this process on the proposed desalination project as well as other alternatives such as additional conservation and water recycling. The Draft Environmental Impact Report (EIR) for the proposed desalination plant was released on May $13^{\text {th }}, 2013$ for public review and comment. 


\section{Challenges to Desalination}

There are three main challenges to the reverse osmosis desalination process.

They are: cost, energy use, and environmental impacts.

\section{Cost}

Historically, cost has been the biggest economic impediment to the implementation of desalination projects, but as local surface and groundwater resources in Santa Cruz County become scarcer and their price continues to rise, cost becomes less of an issue.

This is a function of demand. "Demand for water is an economic concept that is used to describe a want for water backed up by a willingness to pay" ("Desalination: A National Perspective," 2008, p. 42). As technological advances have brought down the price of desalinized water, the point at which the cost intersects with the people's willingness to pay has gotten steadily closer. This has enabled desalinized water "to successfully compete with conventional water resources for potable water supplies" (Reddy \& Ghaffour, 2007, p. 341). (Orbach, 2012)

\section{Energy Use}

Energy use, while associated with cost, has its own set of challenges.

Technological advances in desalination technology have brought down the amount of energy required by the desalination process, but "the energy cost of desalinized water will always be greater than that of traditional water supplies because of the process involved" (Orbach, 2012). A 
desalination plant today only "requires about the same amount of energy as a small manufacturing facility or mid-sized hospital" (scwd2

Desalination Program, 2012). Despite this fact, City and District wanted to ensure that the $s c w d^{2}$ Seawater Desalination Project would not increase the overall energy use of area. The City Council and the District Board of Directors documented this project directive when they "agreed via resolution that the proposed project would be net carbon neutral," meaning that "the proposed project would be designed and operated in such a manner that there would be no net increase in GHG emissions, as compared to the existing environmental setting" (scwd2 Desalination Program, 2013, p. 5.5-23). Under this directive, $\mathrm{scwd}^{2}$ prepared an Energy Minimization and Greenhouse Gas Reduction Plan. The goal of this plan was:

To ensure that advanced and energy efficient desalination technologies and approaches are identified and incorporated into the proposed project design, and to identify additional energy efficiency, renewable energy, and GHG reduction projects and programs to offset all or a portion of the direct and indirect GHG emissions associated with the Project. (City of Santa Cruz Water Department, 2013, Appendix O, p. 2)

Potential GHG reduction projects and programs were required to "meet the regulatory compliance (or eligibility) criteria as outlined in $A B$ 32," and in order to address concerns about carbon offsets, "any third-party reduction offsets or renewable energy credits 
purchased from the voluntary GHG market would need to meet regulatory compliance eligibility standards" (City of Santa Cruz Water Department, 2013, Appendix O, p. 15). The criteria by which reduction projects and programs were identified and evaluated included:

1. Additionality

2. Quantifiable

3. Enforceable

4. Real

5. Permanent

6. Verifiable

The projects and programs identified were composed of three main types: "water and energy efficiency projects, renewable energy generation projects, and GHG reduction/offset projects" (City of Santa Cruz Water Department, 2013, Appendix O, p. 15). The scwd ${ }^{2}$ Energy Team then held workshops to further evaluate and assess these projects and programs. The criteria used in the workshop included:

1. Local Considerations

2. Energy Production, Energy Savings and GHG Reduction

3. Technical Maturity

4. Sustainability 


\section{Reliability and Operational Complexity}

6. Cost / Cost Effectiveness

Using these criteria, the scwd ${ }^{2}$ Energy Team identified 16 GHG reduction projects and programs. These projects and programs were then scored and ranked using "evaluation criteria weightings and sensitivity analysis" that would "illustrate the effectiveness of each of the 16 favorable projects to meet net carbon neutral objective" (City of Santa Cruz Water Department, 2013, Appendix O, p. 17). The scwd ${ }^{2}$ Energy Team reviewed and debated the results and chose 11 projects that were "considered real, verifiable and permanent GHG reduction projects and programs" that were "considered feasible to acquire, implement, and demonstrate reliable GHG reduction potential" (City of Santa Cruz Water Department, 2013, Appendix O, p. 18). These projects, described in terms of their annual GHG reduction potential and lifecycle GHG reduction cost in the Draft EIR for the proposed desalination plant, are listed in Table 1. 


\section{Table 1 - scwd ${ }^{2}$ ETWG Selected Projects and Programs}

\begin{tabular}{|c|c|c|}
\hline Project Title & $\begin{array}{l}\text { Annual GHG } \\
\text { Reduction } \\
\text { Potential }\end{array}$ & $\begin{array}{l}\text { Lifecycle GHG } \\
\text { Reduction Cost } \\
\text { (\$/MT) }\end{array}$ \\
\hline \multicolumn{3}{|l|}{ Water and Energy Efficiency Projects } \\
\hline High efficiency washing machine rebates (accelerated program) & 453 & 600 \\
\hline Commercial and Residential Solar Incentive Program & 246 & $\sim 0$ \\
\hline Implement advanced mixing technologies at SCWWTP & 266 & -45 \\
\hline Implement additional energy savings at SCWWTP & 329 & -215 \\
\hline Improve pump \& motor efficiency (accelerated program) & 29 & 980 \\
\hline \multicolumn{3}{|l|}{ Renewable Energy Projects } \\
\hline Program to convert food waste to energy at SCWWTP & 810 & 276 \\
\hline $\begin{array}{l}\text { Invest in renewable energy projects instead of purchasing power } \\
\text { from PG\&E }\end{array}$ & $\begin{array}{l}\text { Variable (as } \\
\text { required) }\end{array}$ & $\begin{array}{l}\text { Variable (as } \\
\text { required) }\end{array}$ \\
\hline Install local solar projects & 750 & 580 \\
\hline $\begin{array}{l}\text { Install micro-hydropower turbine at Graham Hill WTP and Newell } \\
\text { Creek Dam }\end{array}$ & 147 & -390 \\
\hline \multicolumn{3}{|l|}{ GHG Reduction and Offset Projects } \\
\hline Use Recovered $\mathrm{CO}_{2}$ from local sources for desal process & 70 & 475 \\
\hline Purchase certified GHG Offsets & $\begin{array}{l}\text { Variable (as } \\
\text { required) }\end{array}$ & $15-50$ \\
\hline Total GHG Reduction Potential & \multicolumn{2}{|c|}{ At least $3,100 \mathrm{MT}$} \\
\hline
\end{tabular}

Initially, the project would meet the net carbon neutral objective by purchasing certified offsets, but then "both agencies my assemble a 
feasible and reliable portfolio of energy minimization and GHG reduction projects and programs," such as the ones listed above, "to replace some or all of the GHG credit from certified offset purchases" (City of Santa Cruz Water Department, 2013, Appendix O, p. 20). Some environmental advocates, however, believe that carbon offsets, certified or not, are based on questionable accounting, and that they may not, in fact, reduce carbon in the atmosphere. The carbon offset system, however, like all mitigation, is based on an accepted principle of paying for positive changes elsewhere to balance out any negative impacts of a project, and in this specific project they would only be used until the agencies could implement local projects and programs to replace them. This system of tradeoffs is an integral component of both the policy process and CEQA.

\section{Environmental Impacts}

The two main areas where seawater desalination plants can have an impact on the local biophysical environment are the intake process and brine disposal. In terms of the intake process, the main factor in determining the level of impingement and entrainment of aquatic biota is the location of the water intake. These issues can be addressed through mitigation at the intake point.

Different screen sizes, rotating screens, depth of intake pipes, and the use of subsurface intakes can lessen or eliminate the problems of impingement and entrapment, but which strategy will work best and be most cost-effective varies by location. (Orbach, 2012) 
The Draft EIR for the scwd ${ }^{2}$ Seawater Desalination Project conducted modeling that "did not take into account any potential reduction in entrainment that could be achieved by using a screen or screens on the intake" so that the results would represent a "worst-case' scenario," despite the fact that screens "would be a design feature of the proposed project" (City of Santa Cruz, 2013, p. 5.2-40 and 5.2-41). Analysis of results "shows that even for those species with the highest estimated entrainment, less than $6 / 100$ ths of 1 percent of their source water populations would be at risk of entrainment," and that the number of larvae at risk of entrainment annually "would represent the lifetime reproductive capacity of a single female fish" (City of Santa Cruz, 2013, p. 5.2-41 and $5.2-42)$.

Brine disposal can also take many forms. Strategies for disposing of brine include: "surface water discharge (e.g., into oceans, seas, estuaries, lakes, rivers), wastewater discharge, injection into underlying aquifers, land application, evaporation ponds, and disposing of the salts in landfills after thermal evaporation" ("Desalination: A National Perspective," 2008, p. 125). In the case of Santa Cruz, the proposed plant would send its brine to the award-winning City of Santa Cruz Wastewater Treatment Facility (WWTF) to be mixed in with treated wastewater and released in to the Monterey Bay. The brine "would be blended with less salty water coming from the existing WWTF to dilute the brine to match ocean salinity" 
and "new valves on the existing discharge ports of the WWTF outfall would help spread the combined effluent along the entire diffuser length providing for improved mixing and better control of flow rates" (scwd2 Desalination Program, 2013, p.15). Regarding the intake process and brine disposal, the Draft EIR concluded that:

With the implementation of environmental design features, the operation of the proposed seawater intake system and brine discharge via the existing WWTF ocean outfall would not: (1) have a substantial adverse effect on special-status or other marine species; (2) substantially reduce the habitat of a fish or wildlife species; (3) cause a fish or wildlife population to drop below self-sustaining levels; or (4) threaten to eliminate a plant or animal community. (City of Santa Cruz, 2013, p. 14) 


\section{Current Political Climate in Santa Cruz County}

\section{Local Opposition}

Local opposition to the proposed desalination plant is led by Desal Alternatives. Founded by Rick Longinotti, Desal Alternatives appeared on the scene in 2010, eventually championing Measure $\mathrm{P}$ and most of the campaigns to solicit public comment against the Draft EIR and the proposed desalination plant. The group is several hundred members strong and is very vocal and visible at City Council meetings, Water Commission meetings, and in local media such as the Santa Cruz Sentinel, the major newspaper in the City of Santa Cruz. In addition to commenting at public meetings and conducting email campaigns on critical issues such as the Draft EIR, the group holds informational events and house meetings. The group also works with many other well-known local antidesalination activists such as Paul Gratz, who co-authored Measure P, and Gary Patton, a five-time member of the County Board of Supervisors and environmental lawyer who lectures at the University of California, Santa Cruz. Patton also has a five minute weekly radio show called "The Land Use Report" on local radio station KUSP.

\section{Measure P}

Measure $\mathrm{P}$ was a question on the November 6,2012 , ballot for voters in the City of Santa Cruz. It asked voters: "Shall an amendment to the Charter of the City of Santa Cruz 'Requiring Voter Approval for Desalination Projects' be adopted?" 
Despite the fact that the City Council had already approved an ordinance saying that voters in the city must weigh in on the desalination plant, some citizens worried that a change in the makeup of the city council as a result of the fall 2012 elections could lead to a vote to repeal the ordinance. These residents "felt that it would be better to lock-in the right of residents to vote on the proposed facility by turning the 'right to vote' measure into a citizen-initiated plan" ("City of Santa Cruz Voter Approval", 2014). 5,442 signatures were required in order to put Measure P on the ballot, and the "Right to Vote on Desal Coalition" collected and submitted 8,715 signatures, so the measure was put on the ballot ("City of Santa Cruz Voter Approval", 2014).

The "Right to Vote on Desal Coalition", local anti-desalination activists, and several environmental groups such as the Sierra Club and the Surfrider Foundation supported the measure. In a San Jose Mercury News article in the summer of 2012, however, Paul Gratz, a leader of the "Right to Vote on Desal Coalition", indicated that the real reason behind the push to put any desalination proposal to a public vote. Instead of pursuing desalination, which the City and District had come to as their preferred option after years of studies, public input, and outreach, in the opinion of Gratz and the opposition, "the city should focus instead on regional collaborative solutions that coordinate water supply and storage management, inter-district water transfers and reuse, water neutral development, community engagement, and robust conservation practices and incentives" (Brown, 2012). All of the options and strategies listed in his 
recommendation were either already being put into practice or would be considered and eliminated as inadequate in the alternatives section of the Draft EIR. It appeared that, for the opposition, it was about both the general public's right to vote and the ability of the opposition to sway public opinion against the City and District's 'preferred option' of desalination.

Arguments against Measure $P$ in the official voter pamphlet were signed by: Neal Coonerty, a former Mayor of Santa Cruz and current County Supervisor; Mike Rotkin, a five-time Mayor of Santa Cruz, former lecturer in the Community Studies department at UCSC, union organizer, and member of the Sustainable Water Coalition; several other environmental and community activists; and a trustee of the Santa Cruz City Schools. The official statement in the official voter pamphlet focused on the confusion caused by anti-desalination groups collecting signatures, claiming that "Those gathering signatures didn't explain that the measure would simply cause a vote on whether or not there should be a future vote on desalination" ("Argument against measure," 2012). The statement also pointed out that, because the city had already adopted the ordinance affirming citizens' right to vote on any proposal involving desalination, supporters of the measure were proposing that $\$ 70,000$ of taxpayer money be spent on putting a measure that mirrored existing law on the ballot.

On November $6^{\text {th }}, 2012$, Measure $P$ passed by a margin of 19,124 votes (72.13\%) to 7,389 votes (27.87\%)(“City of Santa Cruz Voter Approval” 2014). 


\section{What Measure P Means}

Following the election, opponents of the proposed desalination plant claimed that 'the overwhelming 'yes' vote suddenly means not just that voters want the right to vote on the issue, but that Santa Cruz doesn't want a plant at all" (Pierce, 2013). The people who voted in favor of Measure P make up a small minority -$14.9 \%$-- of the total population of 128,000 that would be served by the proposed desalination plant. The vote was also held in the City of Santa Cruz, so it excluded the 38,000 residents served by the District, where " $62 \%$ of residents would like to solve our water supply problem with a new source of supply" (Soquel Creek Water District, 2014a). All 26,513 people who voted in the November $6^{\text {th }}, 2012$ election only make up $20.7 \%$ of the residents who receive water from the City and the District, meaning that almost $80 \%$ of the Santa Cruz County residents served by the City and District did not weigh in on the issue.

The combination of lack of public participation and activism on the part of opponents of desalination allowed the public process to be significantly influenced by a small group of citizens, possibly at the price of the greater community. The issue of the appropriate distribution of power in regards to a municipal water supply project will be explored in more depth in the Los Osos Community Services District case study below. 


\section{Public Comment Period for the scwd2 Draft Environmental Impact Report}

The Draft Environmental Impact Report for the proposed desalination plant was released on May $13^{\text {th }}, 2013$. The Lead Agencies "formally issued a Notice of Availability stating that the Draft EIR was available for a 60-day public review period from May 13, 2013 until July 15, 2013," which "constituted an extension of the normal 45-day review period required by CEQA" (URS, 2013, p.2). Public hearings were held on June $3^{\text {rd }}, 2013$ and July $1^{\text {st }}, 2013$ to take comments on the Draft EIR. As a result of both the type and number of comments received, the decision was made to extend the public comment period another 30 days, until August $12^{\text {th }}, 2013$ "to provide more time for the public to participate in the review process" (URS, 2013, p.2).

The public was notified of the availability of the Draft EIR and the public comment period in multiple ways:

- Notices of Availability (NOA) and NOA mailers were sent to "local agencies, relevant regulatory agencies, and property owners and occupants within approximately 300 feet of the project area" (URS, 2013, p.4);

- A press release was sent to local media outlets;

- Advertisements were placed in local newspapers;

- Notices were sent via email to addresses on the project email list;

- Information was posted on the scwd ${ }^{2}$ project website; and

- Information was posted on-site at the project locations. 
Notices "included a brief description of the project and information on the opportunities for public input, including information about the date, locations, and times of the public hearings" (URS, 2013, p.4). Similar notifications were sent out notifying the public of the extension of the public review period in late June and early July.

In addition to the opportunity to submit written comments, the City and District also held two public hearings to solicit verbal comments. For the District's service area, the public hearing was held at the Seacliff Inn in Aptos from 12:002:30 p.m. on June $3^{\text {rd }}, 2013$. Public participation included 76 participants who signed in, of whom 26 provided verbal comments during the oral comment period. For the City's service area, the public hearing was held at the First Congregation Church in Santa Cruz from 6:30-9:00 p.m. on July $1^{\text {st }}, 2013$. Public participation included 226 participants who signed in, of whom 48 provided verbal comments during the oral comment period (URS, 2013, p.8). These hearings were made up of a 30-minute open house, a 30-minute presentation, and an oral comment period allowing attendees to submit their comments verbally. Comments were transcribed by a court reporter (URS, 2013, p.8). 


\section{Public Comments on the Draft Environmental Impact Report}

There were 405 total comments received on the Draft EIR, made up of 331

written comments and 74 verbal comments from "approximately 300 separate individuals, organizations, or agencies" (URS, 2013, p. 10).

Current Status of scwd2 Draft Environmental Impact Report

The City's Actions and Fallout

Figure 4 - Santa Cruz Sentinel, August 19th, 2013

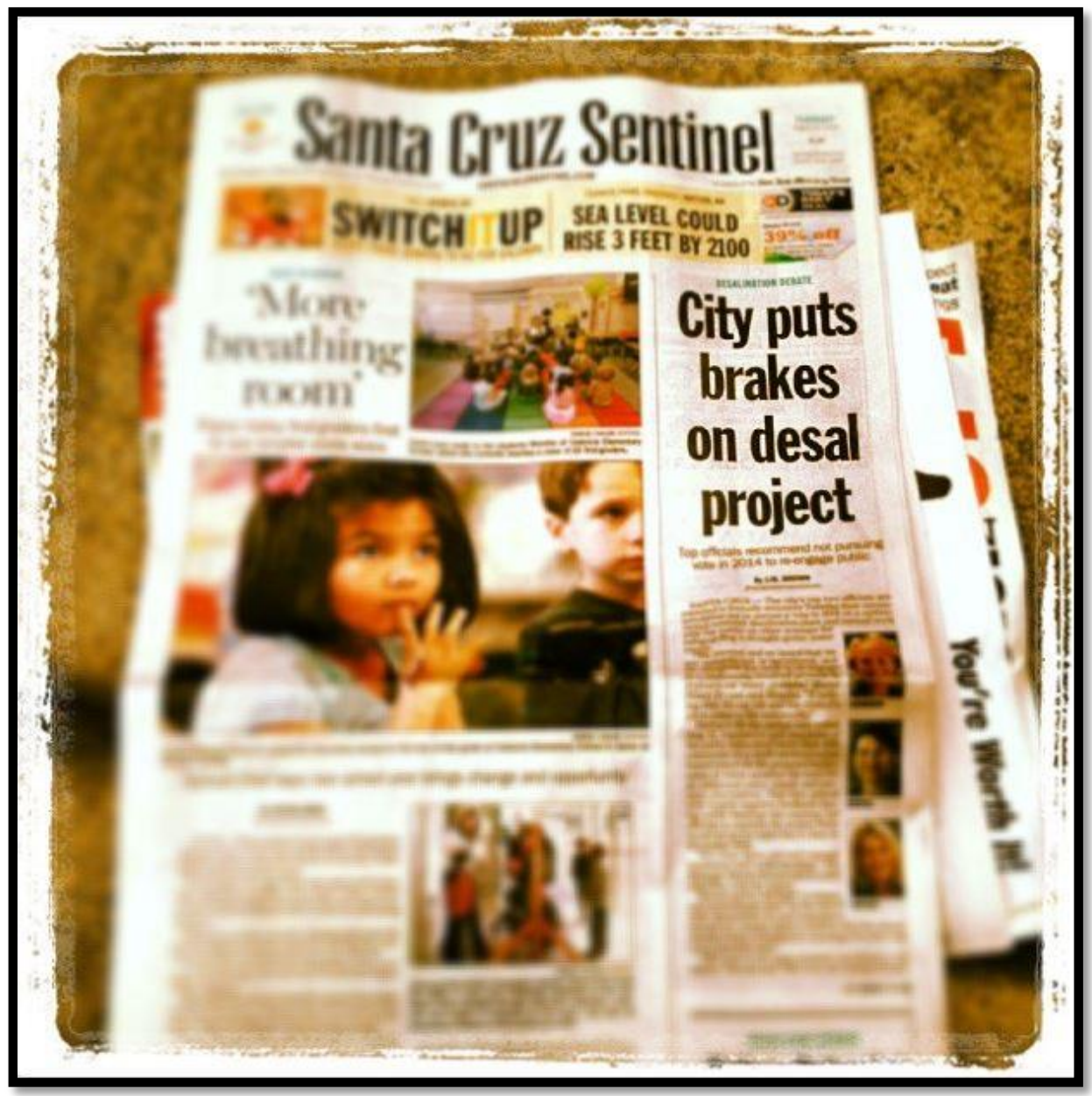


On August 19th, 2014, a week after the 90-day public comment period for the Draft EIR for the proposed desalination plant ended, Mayor Hilary Bryant and City Manager Martin Bernal publicly "announced their recommendation not to pursue a vote in 2014 on a controversial seawater desalination plant and instead work with the public on other avenues for safeguarding a drought-prone water supply" (Brown, 2013a). This move was taken without consulting the District, and sent both water providers scrambling to put a positive spin on what happened. In the press release from Bryant and Bernal, they stated that "The Santa Cruz community is not ready for desalination at this time and we need a reset in the ongoing conversation on water supply and desal issues" (Brown, 2013a). The theme of a 'reset' process caught on in the media and with opposition groups, and came to dominate the public process in the City. In the District, however, where the issue of finding a supplemental water supply is much more time sensitive due to the state of their overdrafted aquifers, they went a different route. Kim Adamson, general manager of the Soquel Creek Water District, stated that "the district intends to continue pursuing desal and must consider, as alternatives, when to enact 35 percent rationing or a moratorium on new hookups" (Brown, 2013a).

\section{Outcomes for the City}

The City, after hitting the brakes on the Draft EIR process, found themselves in the position of having to discuss with the public whether or not to even finish the EIR process at all. Opposition groups smelled blood in the water after the City's 
reaction to their public comments, and they continued pressing the City Council at their meeting on October 8th, 2013. The meeting included "75 minutes of public testimony -- most of which opposed the joint desal project with Soquel Creek Water District" (Brown, 2013b) before council members began their own discussion of the issue. At the heart of the discussion were three main issues:

1. Whether to spend a projected $\$ 300,000$ on responding to the public comments on the Draft EIR;

2. Whether to finish the Draft EIR after responding to public comments at an unknown cost; and

3. How to set up a committee made up of community members to "explore alternatives and their impacts on energy use, neighborhoods and marine life, while taking a close look at demand and conservation" (Brown, 2013b).

Opponents of desalination argued against finishing the Draft EIR, claiming that too much money had been spent already and that the focus should be put on exploring alternatives. Others argued that not finishing the Draft EIR, which would provide the City and District with valuable information about desalination and all of the other alternatives considered, would mean that the combined $\$ 15$ million dollars and over ten years of work that the City and District had spent working to find a supplemental water supply would be wasted. The City shelved the Draft EIR indefinitely, releasing but not responding to comments, and moved 
forward with the formation of a community committee to review the City's water profile.

The City has now created a 14 member Water Supply Advisory Committee (WSAC), whose purpose is "To explore, through an iterative and fact-based process, the City's water profile, including supply, demand and future threats, and analyze potential solutions to deliver a safe, adequate, reliable and environmentally sustainable water supply, and develop strategy recommendations for City Council considerations" ("Water supply advisory," 2014).

\section{Outcomes for the District}

The District moved forward with an exploration of water supply options available to them should the joint desalination program not be revived. They held a series of exploratory meetings between September $17^{\text {th }}, 2013$, and April $1^{\text {st }}, 2014$, about several alternatives to the proposed $s c w d^{2}$ desalination project:

- Regional desalination options;

- Surface water options;

- Mandatory water rationing/demand reduction options;

- Recycled water options; and

- Other groundwater options. 
On June $3^{\text {rd }}, 2014$, the District will discuss the possibility of declaring a groundwater emergency and imposing a moratorium on new water hookups. Then, on August $26^{\text {th }}, 2014$, the board will begin the backup option evaluation process ("Soquel creek water," 2014). While the District has moved quickly through an alternative review process similar to the one being undertaken by the WSAC, it doesn't appear that there is a stand out alternative better than the proposed scwd ${ }^{2}$ Joint Desalination Project. Meanwhile, the District plans to roll out mandatory rationing in the fall of 2014 . 


\section{Rationale for Creating an Advocacy Organization}

Advocacy is defined as "the act of pleading for, supporting, or recommending; active espousal" (advocacy, 2014). The nonobjective nature of the act of advocacy is what sets it apart from communication and education. It is also the reason why many organizations that function under an assumption of objectivity, such as public trust governance institutions and charitable organizations, are prohibited from engaging in activities that could be considered advocacy. Advocacy, however, is an essential part of the policy-making process. "Advocacy is individual or group activism supporting a particular approach or outcome based on shared culture, perceptions, and preferences," and without it, "policy processes would never be productive" (Orbach, 2014).

\section{Summer Internship}

Between June and September of 2013, I worked as an intern at the Soquel Creek Water District. This internship consisted of strategic public outreach and planning efforts supporting the agency's long-term goals of ensuring water supply reliability, maintaining water quality, and protecting the environment. Initially, I worked with the outreach team and their consultants, MIG, to develop phone survey questions regarding customers' current attitudes and perceptions on the water shortage challenges, water conservation, and potential supply options that could be used as a baseline for targeting future outreach and gauging its effectiveness. I also helped identify important community stakeholders and facilitated one-on-one interviews with them. The main focus of my internship, 
however, was developing the framework for a system dynamics model illustrating how water supply conditions impact the community in terms of housing, employment, jobs, and quality of life.

At the time of my internship, the City and District were in the final phases of the CEQA process for a proposed desalination plant project that they had been working on together for over ten years to address the need for a supplemental water supply in the area. As the District's representative for the scwd2 Desalination Program, my supervisor and the City's Desalination Program Coordinator were charged with informing the public about the precarious water situation in the county and the importance of obtaining a supplemental water supply. Relations between the members of both municipal water providers, as well as other political figures, technical advisors, and members of the public were generally very candid and cordial. During the public comment period of the Draft EIR for the project, however, when opponents submitted several hundred negative comments, the Santa Cruz City Council decided to halt the project in a very public fashion without consulting the District. As a joint program, and one in which the District held a much more urgent and time sensitive stake due to their reliance on overdrafted groundwater as their only water supply, this caused a large amount of professional discord between the two agencies. It also resulted in some of my projects being either put on hold or adapted to include the sudden policy and program shift. 
During this tumultuous time, I noticed that only one side of the debate was being represented in the local media. SCWD, SqCWD, and the $\mathrm{scwd}^{2}$ Desalination Task Force were producing large volumes of high-quality outreach material, but because they were public organizations they were unable to engage in any activities that could be construed as actively espousing one particular water supply alternative, even though this directly conflicts with the idea of having a 'preferred option' in an EIR. Anti-desalination groups took advantage of this fact, making their agenda heard at every opportunity, including quotes in most newspaper articles, speakers at public meetings, and letter-writing campaigns. Being a part of one of the organizations that had to experience the results of more than ten years of hard work significantly affected by a small but vocal wave of opposition made me realize that, if the general public was going to have the final say on the Draft EIR or any future project like it, there needed to be a nongovernmental organization more effectively representing the work and interests of the two local water districts and the silent majority of their water customers who were not actively engaged in the political process surrounding the search for a supplemental water supply.

\section{Why Nonprofit Advocacy?}

There are many types of organizations that can influence public opinion and public policy, such as 501(c)(3) nonprofits, for-profit corporations, and political action committees. After reading multiple articles on the topic, the consensus was that the determination of what type of organization you should start depends 
on your motivation and the goals you want to achieve. I had three main purposes for starting an organization:

1. To advocate stewardship of surface and groundwater resources in Santa Cruz County;

2. To provide educational activities focusing on the status of water resources in Santa Cruz County, options for supplemental water supplies, conservation, and links between water quantity and the local economy; and

3. To advocate best conservation practices, protection of local water resources, protection of the economic vitality of the area, and water supply security.

None of these three motivating factors had to do with the organization making a profit, and the first two were not overtly political. The organization I had in mind fell in the nonprofit spectrum, but it had to have the ability to participate in environmental policy-making, "a human values-based process that relies on the production of scientific data and information and effective facilitation and advocacy," which "is always essentially a political process and always involves tradeoffs among objectives and impacts" (Orbach, 2014). The decision concerning which type of nonprofit advocacy group to proceed with is covered in the next chapter, and anticipating that discussion we will first look at several examples of effective nonprofit advocacy groups. 


\section{Case Study - Los Osos Community Services District}

Los Osos is an unincorporated community located in close proximity to the ocean on California's central coast. All water for the community is extracted from groundwater in the Paso Robles Formation, a coastal aquifer confined to the Los Osos Valley. The community was developed without a central wastewater collection and treatment system, with structures disposing of wastewater through individual septic tanks and leach fields (San Luis Obispo County, 2008).

Septic tanks operate by separating solids from raw sewage and allowing the remaining liquids to filter back into the soil through leach fields, which depends on the soil to disperse pollutants. The solids are periodically pumped out of the tanks manually. In order to avoid groundwater pollution in an area with a shallow groundwater table, such as Los Osos, the leach field must be an adequate vertical distance from the groundwater or nitrates will end up in the groundwater and eventually the potable water supply (San Luis Obispo County, 2008).

Starting in 1971, the California Regional Water Quality Control Board (RWQCB) became concerned with the safety of this sanitary system due to "the high level of variance in depth to the ground water, which in certain areas is shallow enough to flood leach fields during wet weather" and the fact that "many of the smaller lots do not contain sufficient land area to accommodate leach fields" (San Luis Obispo County, 2008, p. 1-4). The RWQCB adopted "an interim Basin Plan in June of 1971, which contained a provision prohibiting septic system discharge 
in the area after 1974" (San Luis Obispo County, 2008, p. 1-4). The problem, however, was not adequately addressed, so in 1983 the RWQCB adopted Resolution 83-13, which "established a 'groundwater prohibition zone'” which "prohibited discharge of waster from septic systems within the prohibition zone after November 1, 1988" (Taxpayers, 2005). Resolution 83-13 also "established a timetable for the District [sic] to 'Begin Design, Complete Design, Obtain Construction Funding, Begin Construction, Complete Construction"' (Taxpayers, 2005). The County and the County Services Area No. 9 Advisory Group produced a plan for a wastewater treatment plant, and a 1987 EIR and 1988 Supplemental EIR allowed the project to move into the design phase. In the mid1990 's this plan was modified, moving the facility from the rural outskirts to a partially developed area of the Los Osos community. This modification resulted in community opposition to the plan. Concerns about the project included:

- The cost of constructing, operating and maintaining the project;

- The potential for the proposed disposal system and the volume of wastewater being introduced on the disposal site to result in the daylighting of discharge treated effluent down-slope;

- The use of percolation ponds and their susceptibility to rupture; and

- The potential for increased liquefaction potential and flooding down-slope from the disposal site (San Luis Obispo County, 2008, p. 1-7).

In the meantime, water quality in the area continued to deteriorate. In 1995, the RWQCB issued a study titled "Assessment of Nitrate Contamination in Ground 
Water Basins of the Central Coast Region Preliminary Working Draft", which showed "significant increases in nitrate concentrations over time in both the upper and lower aquifers" (San Luis Obispo County, 2008, p. 1-8).

In 1998, the community voted to create a community services district to take over wastewater authority for the area, forming the Los Osos Community Services District (District). In 1999 the RWQCB issued four cease and desist orders against the District "because of a continuing violation of the previously ordered prohibition of discharge of waste from septic systems" (Taxpayers, 2005). The District responded to the cease and desist orders in the way Resolution 83-13 originally intended, "proposing the construction of a wastewater collection system and wastewater treatment plant to serve the prohibition zone" (Taxpayers, 2005) located at a site commonly referred to as the 'Tri-W' site. The plan was approved in 2000 and a Time Schedule Order established a timetable for the implementation of the plan. The Time Schedule Order was designed to address the issue of the District's past failure to react to RWQCB resolutions and orders, stating that "the history of delayed compliance with the Basin Plan Prohibition indicates that substantial inducement is necessary to assure that the District will achieve compliance" (Taxpayers, 2005). This inducement set specific dates for phases of the implementation plan and imposed "a penalty of $\$ 10,000$ for each day the District fails to complete a task in compliance with the time schedule" (Taxpayers, 2005). Despite the specific dates and non-compliance penalties, the District missed all of the deadlines. Work on the project continued, however, and 
the EIR was certified on March 1, 2001. The project received a Coastal Development Permit (CDP) from the California Coastal Commission and started construction in 2005, but in a special election held in the fall of 2005 a majority of the District board members were recalled and "the new board immediately halted construction on the wastewater project" (San Luis Obispo County, 2008, p. 1-8). The new board members also rescinded the certification of the $2001 \mathrm{EIR}$ for the project and filed for federal bankruptcy protection because their actions caused them to default on State grants and loans.

\section{Measure B}

In 2005, residents also put Measure B on the ballot. This measure was designed to "determine whether a proposal to permit or construct a wastewater treatment facility, whether inside or outside the boundaries of the Los Osos Community Services District ("the District"), shall be subject to a majority vote of the district electors ("the voters")" (League, 2005). In addition to requiring any proposed wastewater treatment facility to be subjected to a public vote, the measure included a list of criteria required before a proposal could be submitted to the voters. These criteria included:

1. The facility may not be located in close proximity to "public gathering places" where individuals would be subject to exposure to noxious odors or toxic chemicals emanating from or used by the facility; 
2. The facility must be subject to full environmental review under applicable California or federal environmental quality laws;

3. The proposal must include alternative site proposals, including a "no project" alternative, as identified by any environmental review;

4. The proposal must identify on the ballot which proposed facility is recommended by the District and which is the least environmentally damaging project;

5. The California Coastal Commission and other appropriate agencies must be given an opportunity to comment on the proposal, which comments must be made publicly available at least 60 days prior to the election on the proposal; and

6. All information relating to the facility site must be made available to any resident of the District for review (League, 2005).

Arguments in favor of Measure B included the cost of the proposed project, the location of the proposed project, and environmental concerns about the project. Arguments against Measure B included:

- The fact that it would not move the sewer;

- That it would increase the cost of implementing wastewater solutions;

- That it would invite costly lawsuits; and

- That a 'no project' alternative was not a viable alternative since the District was under a state mandate to complete a wastewater treatment project (League, 2005). 
On September $27^{\text {th }}, 2005$, Measure B passed by a narrow margin, with 3,289 'yes' votes (50.2\%) and 3,269 'no' votes (49.8\%) (League, 2005).

\section{Taxpayers Watch v. Los Osos Community Services District}

In December of 2005, Taxpayers Watch, an unincorporated association, and several other individuals filed a Petition for a Writ of Mandate "to declare an initiative that establishes standards and procedures for the siting of sewer and wastewater treatment facilities (Measure B) to be invalid and void" (Taxpayers, 2005). The defendant and respondent to the Petition was the Los Osos Community Services District. The petitioners' argument hinged on three main ideas:

1. That the siting of a wastewater treatment facility is an administrative one and not a legislative one, and that an initiative (such as Measure B) can only address legislative acts;

2. That the initiative interferes with essential government functions; and

3. That the District is judicially estopped from taking the position that Measure B is valid (Taxpayers, 2005).

\section{Superior Court Ruling}

On April $13^{\text {th }}, 2006$, Judge of the Superior Court of San Luis Obispo County Martin J. Tangeman issued his Statement of Decision on Taxpayers Watch $v$. 
Los Osos Community Services District. In his statement, Judge Tangeman concluded that "it is the decision of the Court that Measure B is invalid because it is an administrative act and not a legislative act; furthermore, it impermissibly interferes with essential government functions" (Taxpayers, 2005). The Writ of Mandate was then issued, declaring Measure B invalid and void.

\section{Court Rationale}

The Superior Court decision hinged on the fact that the District had been ordered by a state agency multiple times to stop discharging waste materials through septic tanks, establishing "a policy prohibiting on-site sewage disposal in the prohibited zones" and approving "the means of carrying out that policy," referring to "the construction of a wastewater treatment facility by the District" (Taxpayers, 2005). Due to the fact that a state agency, the RWQCB, had already provided both the mandate and approved method of addressing that mandate, the role of the District became administrative rather than legislative, which meant that if Measure B was implemented it would be taking an administrative function from a government body, an action not permitted for initiatives. Similarly, Measure B called for a 'no project' alternative to be included as an option for voters, but because of the RWQCB mandate the 'no project' alternative was not a valid option, meaning that if the initiative was enacted it would give voters the power to unlawfully interfere with essential government functions. 


\section{Measure $B$ and Measure $P$}

Measure B and Measure P are very similar in their goals and intentions. These initiatives:

- Were developed by community members who were unhappy with the actions of local government agencies and wished to usurp the power to make decisions about municipal water projects;

- Put a strong emphasis on the cost, location, and environmental impacts of their respective projects;

- Were passed by a majority of the voters; and

- Stopped the progress of municipal projects that had required years of work and millions of dollars.

The main difference between the two initiatives is that, in the case of the Los Osos Community Services District, they were under a mandate from the RWQCB to not only stop using septic but also to build a wastewater treatment facility, and noncompliance carried with it hefty monetary punishments. While this is not currently the case in Santa Cruz County, the possibility of state mandates regarding water supply are not out of the question. In-stream flow requirements are included in the Habitat Conservation Plan being pursued by the City in order to receive an Incidental Take Permit. Under the Endangered Species Act (ESA), the base fine for killing one member of a protected species is $\$ 3,500$ (First), $\$ 7,500$ (Second), and $\$ 13,000$ (Third) respectively (National Oceanographic and 
Atmospheric Administration, 2001), so there is a significant financial incentive for parties concerned with possible takings to pursue a HCP and ITP. There is a "No Surprises" assurance in section 10(a)(1)(B) that "if "unforeseen circumstances" arise, the FWS will not require the commitment of additional land, water, or financial compensation or additional restrictions on the use of land, water, or other natural resources beyond the level otherwise agreed to in the HCP without the consent of the permit-holder" (U.S. Fish and Wildlife Service, 2011, p.2), but if the City became unable to meet the stream flow requirements in their HCP and human demand due to drought conditions, then financial penalties could possibly be incurred. If this were to occur, a state agency could require the City to attain a supplemental supply that would allow them to meet the needs of residents and endangered fish species, putting Measure $\mathrm{P}$ in the same vulnerable legal position as Measure B.

Measure $B$ and Measure $P$ both deal with the desire of citizens to participate in local municipal water decisions that affect their pocketbooks, quality of life, and environment, but in both instances the line between what is legal and what is not when it comes to the power of ballot initiatives is called into question. In Los Osos, the combination of the recall election and Measure B forced a wastewater treatment facility that had gone through all state mandated environmental review processes and was already in the construction phase to be halted. This not only forced the District to file for bankruptcy, but also negated years of progress towards fixing an environmental problem that endangered the health of the entire 
community. Even though Judge Tangeman's decision made Measure B invalid and void, the damage had already been done, setting Los Osos back years in addressing their groundwater pollution problem.

In Santa Cruz County, where the supporters of Measure P make up only $14.9 \%$ of the population that will be served by a joint program between two municipal water providers, Measure $\mathrm{P}$ helped derail a project that involved more than ten years of work and over $\$ 15$ million of taxpayer money. By the time the WSAC finishes their review of the water supply alternatives contained in the Draft EIR for that project and makes a recommendation, which could even be the same 'preferred option' as before, much of the data from the Draft EIR will be out of date and need to be updated, requiring taxpayers to fund another EIR that covers much of the same information. The delay caused by this repetitive review process only exacerbates the environmental problems that the project was designed to address, costing the entire community more money, and making the entire county more vulnerable to drought and the other effects of global climate change.

The CEQA process requires a significant amount of public outreach, opportunities for public comment, and a high level of transparency for any proposed development that has the potential for significant environmental impact. It is designed that way to that the public can become as informed as possible and then provide input on the proposed project. Initiatives such as Measure P give 
interest groups that only represent a small proportion of the population affected by a proposed project a disproportionate amount of power in the political process, taking the power out of the hands of elected officials who were elected by the community to handle issues such as these. One of the main reasons we have a representative democracy is to let representatives, who are advised by a large body of experts and technicians, to make decisions for the largely silent and less informed majority that make up the 'public'. In the absence of a state mandate to find a solution that would negate Measure $\mathrm{P}$, however, those who recognize the less than democratic nature of the situation must work within the constraints of the new political reality. Given those constraints, nonprofit advocacy is one of the most effective ways of getting a larger proportion of the population informed and engaged in the political process surrounding this critically important issue. 


\section{Starting a Nonprofit Advocacy Group}

\section{SeeWaterSC vs. Sustainable Water Coalition}

During my summer internship with the Soquel Creek Water District, I started a Facebook community group called 'SeeWaterSC' to share the information I was working with on a daily basis with my friends and other interested people in the Santa Cruz community. It quickly grew to over one hundred followers, which got me thinking about whether I could turn it into something more. When I began researching how to start a nonprofit, it seemed only natural to consider turning SeeWaterSC into that organization. The amount of paperwork required seemed reasonable within the timeframe of my Master's project, but when it came to finding potential board members, funding, and actually organizing the entity itself it was much more challenging. Finding potential board members was my primary concern, because while I am very passionate about the topic, most of my friends and acquaintances who are similarly passionate already work for either the City or the District and would not be able to be publicly affiliated with this type of organization. In order to have an organization that was taken seriously in the supplemental water supply debate, I was going to need to find a set of individuals who were well-versed about water and politics in Santa Cruz, not just a few friends who had mainly heard about issues through me. Funding wouldn't be that much of a concern initially, because the filing fees for starting a California corporation are relatively low, and most of the initial networking and infrastructure would be web-based and inexpensive, but it would become more important later on as print, television, and other advertising and materials were utilized. I was 
talking about my idea with my supervisor from the District in November, and she mentioned that I should speak with some of the members of the Sustainable Water Coalition (SWC) to see if they were interested in having me do the same work, but for their organization.

The SWC was a group in name only, without an official Internal Revenue Service (IRS) designation. The SWC was comprised of concerned local citizens who had come together several years earlier to support the work of the City and District to find a supplemental water supply. I had heard their name mentioned, and even tried to set up a meeting with one of their members previously (which never materialized), but they had been conspicuously quiet during the events of the summer and I wasn't sure whether they were still active in the debate. I set up a meeting with Trink Praxel, the main driver of the organization, and Laura Brown, a previous general manager of the District who was a current member of SWC. Over breakfast I informed them about my nonprofit advocacy idea and what it would entail, and they said they would love to have me come and present to their group.

\section{Presentation to Sustainable Water Coalition}

On Monday, December $9^{\text {th }}, 2014$, I met with members of the SWC in a conference room at the Santa Cruz Museum of Art and History at the McPherson Center. Presentation materials are included in Appendix A. The group included a broad mix of interests in the community, including business, commerce, 
politics, and education. At the conclusion of the meeting, the group informed me that they would like me to work with their group. Due to the considerable benefits of working with an already established and well-connected group such as SWC, I agreed.

\section{What the Sustainable Water Coalition Is and Is Not}

It is important to begin by stating what the Sustainable Water Coalition is and what it is not. The Sustainable Water Coalition:

- Was created to work towards a solution to a major local problem;

- Is a nonprofit corporation dedicated to: (1) the stewardship of surface and groundwater resources in Santa Cruz County; (2) educational activities focusing on the status of water resources in Santa Cruz County, options for supplemental water supplies, conservation, and links between water quantity and the local economy; and (3) advocacy for best conservation practices, protection of local water resources, protection of the economic vitality of the area, and water supply security;

- Acknowledges that there are many different water supply options and combinations of options that could help us meet our water needs; and

- Is dedicated to finding the most environmentally, socially, politically, and economically feasible solution to our water supply problem for all residents and businesses in Santa Cruz County. 
The Sustainable Water Coalition is not:

- A lapdog for the City of Santa Cruz Water Department or the Soquel Creek Water District, though we do maintain relationships with people at both organizations due to the fact that they are the ones on the front lines of water resource management in the County collecting data and working towards solutions;

- A group dedicated solely to the implementation of desalination, though we do feel that desalination remains a valid supplemental water supply option that should be considered with all other water supply alternatives.

\section{1(c)(3), 501(c)(4), or Nonprofit Unincorporated Association}

The first important decision we had to make was about what kind of organization we would like to become. There are several options available for nonprofit organizations wishing to engage in advocacy while maintaining tax-exempt status with the IRS, shown in Table 2 below. The differences in the amount of lobbying and advocacy allowed, the ability to apply for grants, and eligibility for receiving tax-deductible contributions vary by type of organization.

\section{Table 2 - Organizational Structure Choice Matrix}

\begin{tabular}{|l|c|c|c|c|}
\hline \multicolumn{5}{|c|}{ Organizational Structure Choice Matrix } \\
\hline & Tax-Exempt Status & Tax-Deductible Contributions & Grants & Lobbying/Advocacy \\
\hline $\mathbf{5 0 1 ( c ) 3 ~ - ~ " C h a r i t y " ~}$ & Yes & Yes & Yes, but limited & Un \\
\hline $\mathbf{5 0 1 ( c ) 4 ~ - ~ " S o c i a l ~ W e l f a r e " ~}$ & Yes & No & \\
\hline $\begin{array}{l}\text { Nonprofit } \\
\begin{array}{l}\text { Unincorporated } \\
\text { Association }\end{array}\end{array}$ & & No & No & Unlimited \\
\hline
\end{tabular}


While tax-deductible contributions are an important benefit when fundraising for a nonprofit, that benefit must be weighed against the advocacy limitations that accompany it. The IRS allows 501(c)(3) charitable organizations to choose between an 'insubstantial part test' and the $501(\mathrm{~h})$ expenditure test to determine the amount of lobbying and advocacy they are engaged in. The "insubstantial part test" is the default, maintaining that lobbying must not be a substantial part of the organization's overall activity. The IRS, however, has not stated what an 'insubstantial' amount of lobbying is or what constitutes lobbying under this test. But "a 1952 federal court decision states that $5 \%$ of an organization's 'time and effort' was an insubstantial part of its overall activities," so "most tax practitioners generally advise that charities can safely devote $3-5 \%$ of their overall activities toward lobbying" ("Lobbying under the," p.1).

Due to the vague nature of the 'insubstantial part test', in 1976 Congress created the 501(h) expenditure test. The 501(h) expenditure test provides "clear dollarbased limits on how much money a public charity can spend on lobbying" (Mehta, 2009). Under this test, "depending on the amount of an organization's exempt purpose expenditures, a charity can generally spend up to 20 percent of its annual expenditures on lobbying" (Mehta, 2009). It also includes clear definitions as to what is considered lobbying, dividing it into two categories: direct lobbying and grassroots lobbying. Direct lobbying is "any communication, with a legislator, that expresses a view about specific legislation," and grassroots 
lobbying is "any communication, with the general public, that expresses a view about specific legislation, and includes a call to action" (Mehta, 2009).

While forming a 501(c)(3) charitable organization and electing to go with the $501(\mathrm{~h})$ expenditure test would allow the organization freedom to engage in a certain amount of lobbying, the main purpose of this organization is advocacy, so any limitations on the amount of time and money spent on those pursuits would be inordinately restrictive to all of the activities of the organization. Forming a 501(c)(4) social welfare organization or a nonprofit unincorporated association would free the group from any and all limitations on their activities.

When I initially met with the SWC working group to discuss working with them on December $9^{\text {th }}, 2013$, I presented them with these options. We weighed the options and decided that the 501(c)(4) social welfare organization structure would work best towards achieving the goals of the organization.

\section{Organizational Documents and Structure}

\section{Articles of Incorporation}

In order to form a California corporation, you must file the organization's articles of incorporation with the California Secretary of State (SOS). Articles of incorporation generally include the name of the organization, the purpose(s) of the organization, the agent of service of process, and any limitations on 
corporate powers, but what is required in articles of incorporation varies state by state. These articles serve to incorporate the organization legally in the state where they conduct their activities.

The first version of the SWC articles of incorporation I sent to the SOS was modelled after several different sets of articles from different states that I came across in my research. The initial version contained eleven articles: name, duration, purposes, members, stock, registered office and agent, amendments to the articles of incorporation, funds and assets, directors, incorporator, and bylaws. I had the articles notarized and mailed them in to the SOS on February $5^{\text {th }}$, 2014. Those articles were returned on February $13^{\text {th }}, 2014$. In the attached letter, a copy of which is included in Appendix C, the Corporation Documents Examiner wrote that "the Articles of Incorporation have not been prepared in compliance with the Nonprofit Corporation Law, which became effective on January 1, 1980" (E. Resurreccion, personal communication, February 13, 2014). Attached to the letter was a form that included the information that would meet the minimum requirements for filing with the SOS. The required articles were: corporate name, corporate purpose, service of process, corporate address, and additional statements. I modified the articles of incorporation, and then called and spoke with someone at the SOS office to make sure that the second version would meet state requirements and then sent them in. During the conversation I also learned that the articles did not have to be notarized. 
The second version of the SWC articles of incorporation included the required articles listed above as well as several additional articles: duration, members, stock, amendments to the articles of incorporation, by-laws, directors, and incorporator. The second version of the articles of incorporation was returned on March $14^{\text {th }}, 2014$. In the letter, a copy of which is located in Appendix C, the Corporation Documents Examiner explained that "pursuant to California Corporations Code sections 5120(b), the concept of 'incorporator' is pertinent only if no directors have been named" (C. Baccari, personal communication, March 14, 2014). By including an article with a list of initial directors, I had unknowingly changed the requirements for the articles. The letter went on to explain that, because directors had been named, "any reference to the 'incorporator' must be deleted," and furthermore that "the named initial directors must sign the document at the end and then separately acknowledge their signatures as provided in California Corporations Code section 5030(b)" (C. Baccari, personal communication, March 14, 2014). When I called and spoke with a SOS representative, I informed them that it would be difficult for me to attain signatures from all of the initial board members because one of the members was out of the country. The representative then explained to me that the easiest solution would be to leave out the article that included the list of initial directors, because it wasn't a required article, and leave myself as the sole incorporator. I removed the article that listed the initial directors and resubmitted the articles to the SOS office. 
On March $25^{\text {th }}, 2014$, the 501 (c)(4) Articles of Incorporation for Sustainable Water Coalition, Inc. were officially filed with the California Secretary of State. I received the official copy of the articles stamped 'FILED' and initialed by the Corporation Documents Examiners in the mail with a packet of information about other requirements for nonprofit corporations. The articles were also stamped with our official California Secretary of State Corporation Number. A copy of the final articles of incorporation and the two letters from the SOS are in Appendix B and Appendix $\mathrm{C}$ respectively.

\section{Bylaws}

A bylaw is "a standing rule governing the regulation of a corporation's or society's internal affairs" (bylaw, 2014). Corporations develop bylaws to control the internal affairs of the organization. Bylaws can cover a wide variety of subject matter, and are generally established by the initial board of directors and/or incorporator. The first bylaws drafted included the following topics: name, purpose, meetings, officers/board of directors, election of officers and board members, rules of order, committees, financial and fiscal affairs, use of the name Sustainable Water Coalition, amendment of bylaws, and dissolution. These bylaws were circulated via email to SWC members in January of 2014, and then they were discussed at the SWC meeting on January $29^{\text {th }}, 2014$. Comments from the meeting were used to make changes, and a final version was drafted. The final version of the bylaws was ratified at the SWC board meeting on May $19^{\text {th }}, 2014$. A copy of the final bylaws is in Appendix D. 


\section{Employer Identification Number (EIN)}

In order to hire employees and start a bank account, a nonprofit organization needs to have an Employer Identification Number (EIN). In order to attain an EIN, an organization must complete and submit IRS Form SS-4, the "Application for Employer Identification Number". I filled out and submitted this form on

January $31^{\text {st }}, 2014$, and we received our EIN on March $19^{\text {th }}, 2014$. A copy of the letter containing our EIN is included in Appendix E.

\section{Statement of Information (SOI)}

California also requires that domestic nonprofit corporations file a Statement of Information form, Form SI-100, with the SOS within 90 days of filing the Articles of Incorporation and then biennially after that. This form requires the corporation to name its chief executive officer (CEO), secretary, and chief financial officer (CFO). At the January $6^{\text {th }}, 2014$ SWC meeting, where we selected our initial board members, we also elected Mike Rotkin as president (CEO) and Trink Praxel as secretary. At the SWC Working Group meeting on May $19^{\text {th }}, 2014$, we elected Tom Manheim as Treasurer, and at Trink's request, the group also passed a motion for me to replace her as Secretary. Form SI-100 for SWC was filed electronically with the SOS on May $21^{\text {st }}, 2014$, listing Mike Rotkin as President (CEO), Tom Manheim as Treasurer, and Matt Orbach as Secretary. A copy of Form SI-100 is included in Appendix F. 


\section{Filing for Nonprofit Status}

In order to attain recognition of tax-exempt status from the federal government and the State of California, a 501(c)(4) social welfare organization must submit IRS Form 1024 (“Application for Recognition of Exemption Under Section 501(a)") and Form 8718 (“User Fee for Exempt Organization Determination Letter Request”) as well as California Form 3500 (“Exemption Application”). The information on these forms can be provided retroactively, however, after the organization has been in operation for several years. This allows organizations to see what their annual expenditures are and gauge what percentage of those expenditures is allowable before filing for tax-exempt status. Filing for taxexemption before knowing what the organization's gross receipts are would give the federal and state government no information upon which they could grant a letter of determination. These forms will be filled out at the end of the SWC's first full year of operation. 


\section{Social Media Infrastructure}

When I started working with SWC, they already had some social media infrastructure in place. They maintained a WordPress website at www.sustainablewatersantacruz.org and a "Sustainable Water Coalition of Santa Cruz County" Facebook page. At the time of my proposal to the SWC group on December $9^{\text {th }}, 2013$, however, neither had been updated since June $29^{\text {th }}, 2013$, so as part of my presentation to the group I proposed that I be added as an administrator of the website and Facebook page. They agreed, and on January $17^{\text {th }}, 2014$, I began posting as SWC on Facebook. I also created a Twitter account for the organization, using the name @SWCSantaCruz.

\section{Facebook Demographics and 'Promoting' - Knowing Your Constituents}

\section{Facebook Demographics}

Facebook offers a good amount of demographic information about the followers of community pages to page administrators under the "Insights" tab. I had become accustomed to looking at this information while running my SeeWaterSC page, and I wanted to see how the demographics of the existing SWC Facebook page would change after I took over. This information could then be used to target advertising and marketing on Facebook and in the Santa Cruz community as well. Figure 5 below shows the demographic information on the 79 followers of the SWC Facebook page before I took over as administrator, and Figure 6 shows the demographics of the 161 followers of the page as of May $12^{\text {th }}, 2014$. 
Figure 5 - SWC Facebook Page Demographics on 1/21/14

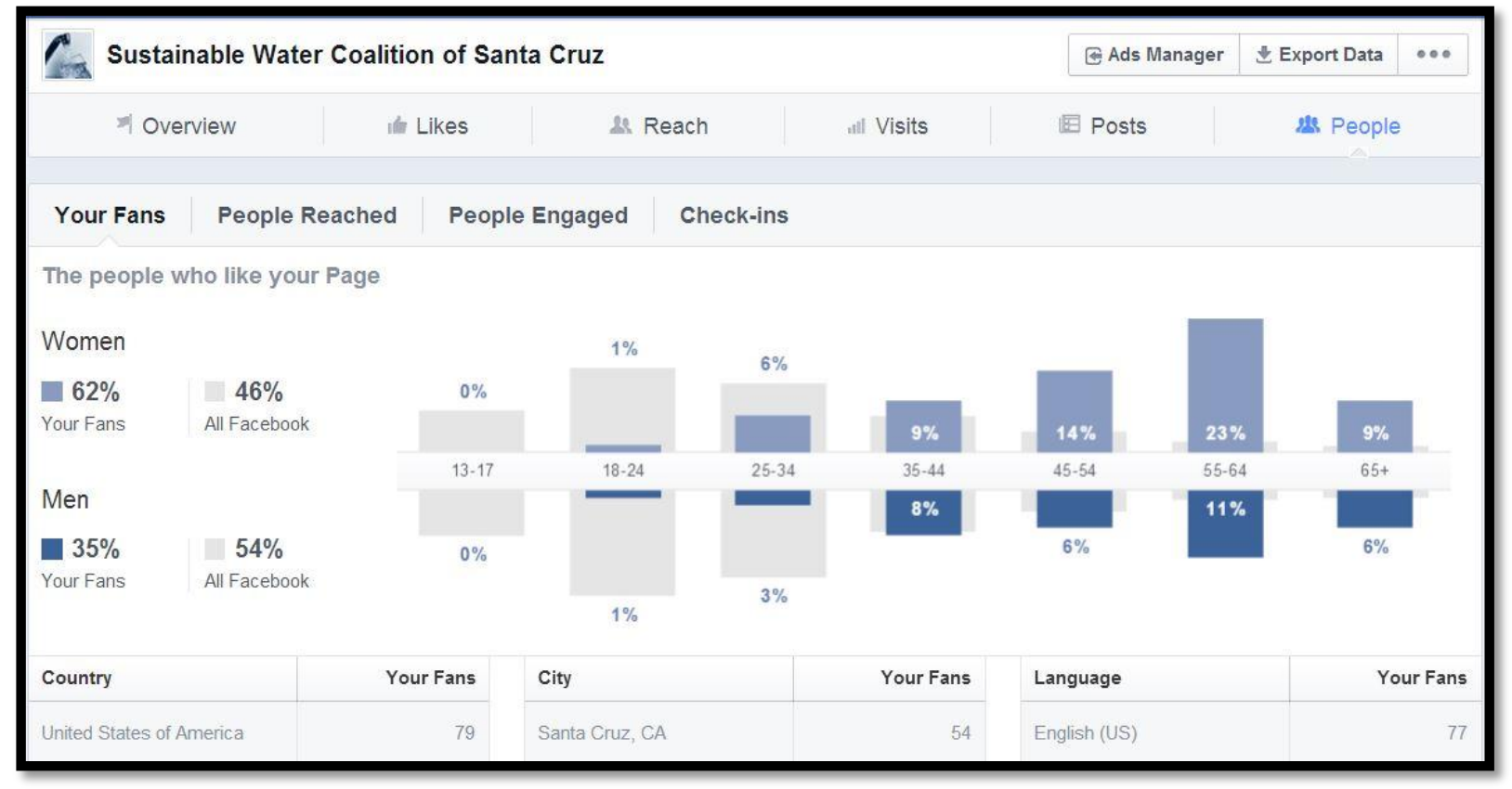

\section{Figure 6 - SWC Facebook Page Demographics on 5/12/14}

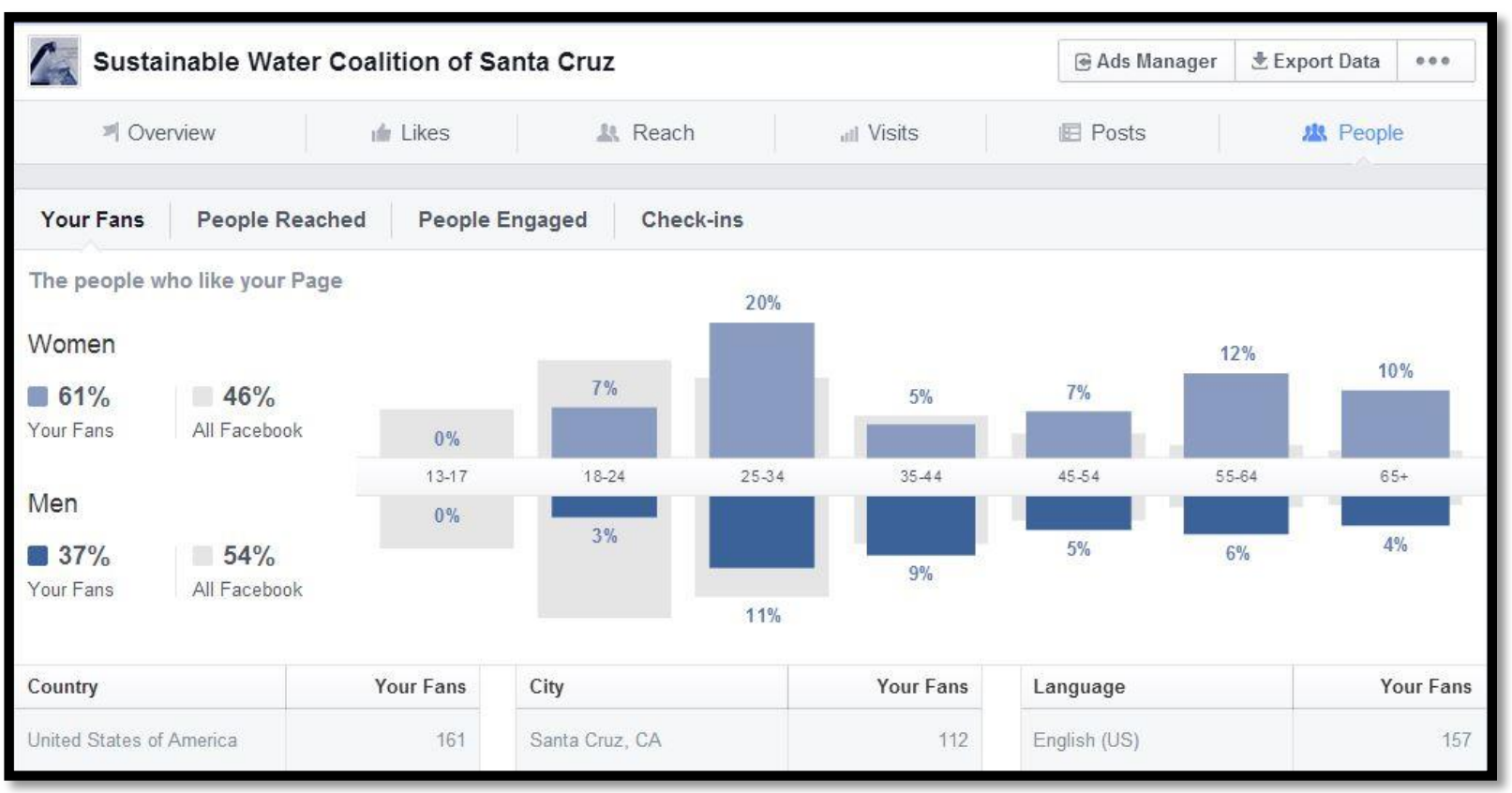


The dark blue bars represent the percentage of followers that fall into each demographic category and the underlying light blue bar represents the percentage of All of Facebook that falls into those same demographic categories. Comparing those two bars for each age cohort illustrates which demographic categories have the most potential for finding new followers. Based on that, and realizing that the configuration of the demographic may change significantly as the number of followers grows, at this point the target would be the 18-24 cohort for both men and women, followed by the 25-34 cohort for men and the 35-44 cohort for women.

\section{Facebook 'Promoting'}

I also researched the paid advertising options offered by Facebook to understand how it could be used for targeted advertising. The two main options are "Promoting Your Page" and "Boosting Your Posts". Promoting is designed to increase the number of followers of your page, increasing both name recognition and general visibility. Boosting a post can be used for sharing important information with Facebook users who may not be interested enough in your cause to follow your page, such as sparking interest in a particularly hard-hitting letter to the editor, getting a targeted message out to a broad audience, or increasing turnout for a meeting or election. I presented this "Facebook Promoting Report", as well as some logo and messaging ideas and examples that I created, at our SWC working group meeting on January $29^{\text {th }}, 2014$. Copies 
of the "Facebook Promoting Report" and the SWC logo examples are located in Appendix $\mathrm{G}$ and Appendix $\mathrm{H}$ respectively.

\section{SWC Outreach Committee}

At our meeting on January $6^{\text {th }}, 2014$, we selected a SWC Outreach Committee made up of myself, Trink Praxel, Tom Manheim, and Mike Rotkin. The SWC outreach committee is in charge of maintaining social media sites as well as reviewing all other public SWC communication items before presenting them to the SWC Working Group.

\section{January 18th, 2014 SWC Outreach Committee Meeting}

At our first meeting on January $18^{\text {th }}, 2014$, we discussed social media outreach such as Facebook and Twitter, marketing, advertising, the website, and timely media responses. I was asked to encourage followers of my SeeWaterSC Facebook community to also follow SWC, which I did shortly after the meeting, raising the number of SWC followers from 79 to 136 in five days. For the marketing discussion, we focused on three main topics: a logo, a tag line, and messaging.

I presented several logo ideas I had created as well as work by other local graphic artists in order to get the committee members thinking about what words and imagery we would like in our official logo. We also discussed creating a tag 
line to go along with the logo and a 2-3 sentence message that more fully explained our organization. Due to the importance and public visibility of these items, we agreed to discuss them further at the next SWC Working Group meeting in order to get input from the larger group.

We all agree that the website needed a massive overhaul. Trink agreed to give me administrative authority for the site and Tom took the lead on reviewing the information currently on the site and recommending revisions and updates that need to be made. Additionally, we decided that the site needed to have a Frequently Asked Question (FAQ) page that people could use for quick reference.

The item of timely media responses was also brought up. We all agreed that, in order to create a more visible presence in the media, we needed to have a system in place for responding to items in the media on which our organization wanted to present an opinion. We discussed a system where one of us would draft a response, send it to the rest of the group via email asking for input within a couple of hours, and once a minimum of two members signed off on the statement it could be sent in. 


\section{March 1st, 2014 SWC Outreach Committee Meeting}

On March $1^{\text {st }}, 2014$, the SWC outreach committee met at Tom Manheim's house to discuss Tom's recommended revisions and updates for the SWC website, what additional information the website still needed, logo design and funding options, and website maintenance and design. The committee went through Tom's comments and edits and agreed with most of the recommendations. The need for several additional sections and pages and further updates to a few other pages was noted, and these sections were assigned to committee members. These sections included: an updated Integrated Water Plan section (Trink), the welcome page (Trink), Santa Cruz Alternatives Explored and Soquel Creek Alternatives Explored pages with links to the Draft EIR (Matt), the energy use page (Tom), and an 'economics of a water system' page (Matt). The goal was to have sections finished and submitted to Tom by Saturday, March $8^{\text {th }}, 2014$. Due to the time constraints placed on me by my other Winter quarter projects, however, I asked to have the deadline extended. It also turned out that no one on the outreach committee was comfortable using WordPress to edit the website, which would prevent us from making changes to the website even if we completed our sections. I registered for CRP-470, "Web Technologies and Planning", for Spring quarter in order to get acquainted with the WordPress software so that I could eventually implement the changes we wanted to make to the website. 


\section{April 8th, 2014, the SWC Email List, and a Domain Name}

On April $8^{\text {th }}, 2014$, I received an email from Bill Tysseling regarding the City Council meeting that evening and the fact that Rick Longinotti and his Desal Alternatives group planned to challenge the City's potential hiring of Stratus Consulting to assist the Water Supply Advisory Committee (WSAC). The email detailed the reasons for Desal Alternatives objecting to the hiring and then requested input on how our group should respond. After reading a few responses from other well-informed SWC members, I crafted a letter and ran it by the group for comment. After making a few changes, I emailed it to the Santa Cruz City Council so that our group could be on record supporting the City's decision. I also posted a modified version of the letter on the SWC Facebook page and urged our followers to copy and paste it and submit it to the City Council as well. Copies of both versions of the letter are in Appendix I. Later in the day another SWC member responded to Bill's initial email that over the course of the previous week or so the City had received over 90 emails from the anti-desalination crowd. This information got me thinking about our organization was never going to get ahead if we were always scrambling to muster support for things at the last minute and generally acting in a reactive rather than a proactive manner. With how well the SWC members are connected in the Santa Cruz community, there was no reason why we shouldn't be able to start campaigning early for issues that we know are going to be contentious. 
I had heard that there was a SWC mailing list that contained over 100 addresses. I inquired about the location of the list, and over the next couple of days I gained access to two separate email lists with a combined total of 210 addresses. I created a MailChimp account, combined the email lists and uploaded them, and set up a template for future email campaigns. I also researched how to include coding in the newsletter so that if the reader wanted to send our form letter, they simply had to click 'HERE' and it linked them directly to their email with the email address of the City Council, subject line, and the form letter text already inserted. Then, as a test, I created an example "SWC Action Alert" newsletter that contained information about Stratus Consulting as well as the link to a form letter and sent it to the SWC board members for comment. The group approved of the format, but several members mentioned that we should wait until after the upcoming WSAC meetings to start gather support for a recommendation to the City Council. We will be discussing the content of the first SWC newsletter at our board meeting on May $19^{\text {th }}, 2014$.

During the process of setting up the MailChimp account it also occurred to me that we would need an email address to which followers could respond in the newsletter. Not wanting to use my own personal email, I began looking into purchasing a domain name. I ended up settling on Google Apps for Business, a new service offered by Google that lets you pick your own domain name, includes email, and offers online storage and many of the other perks associated with Google services. I chose the domain name @sustainablewatercoalition.org 
and started three email accounts: matto@sustainablewatercoalition.org, updates@sustainablewatercoalition.org, and contact@sustainablewatercoalition.org. These email accounts will be used to consolidate incoming public comment from our website and newsletters.

\section{Current Status of SWC Outreach Committee Work}

Work on the website, logo, and advertising will resume after the SWC board

meeting on May $19^{\text {th }}, 2014$. Now that I am comfortable with using the WordPress web editing software, I will be able to implement the changes that the SWC outreach committee talked about at our previous meetings. The meeting should also get the process of contracting a graphic designer to work on our official logo started, which is an important first step towards creating many of the outreach materials we will need for future events, as well as give us the opportunity to discuss the content of our first official SWC newsletter. Further SWC outreach committee meetings will most likely take place after I move back to Santa Cruz in July. 


\section{SWC Strategic Plan}

Now that the initial process of filing organizational documents is nearing completion, it is time for the organization to focus on our strategy for moving forward. Other than having Mike Rotkin representing SWC on the WSAC, the organization remains barely visible. The strategy moving forward should contain the following actions:

- Update the website with the information discussed in the SWC outreach committee meetings;

- Start publishing a monthly newsletter;

- Design, purchase, and distribute merchandise containing our logo and messaging; contact local journalists, such as Santa Cruz Sentinel reporter J.M. Brown, to get quotes in articles about water supply issues;

- Conduct a survey to determine what people know about water in the City and District and where they get their information; and

- Begin the process of organizing events to share information and our organization's advocacy positions and statements with the public. 


\section{Summary of process}

The process of getting the Sustainable Water Coalition set up as a California nonprofit corporation took roughly six months, but will not be complete until we file our IRS Forms 1024 and 8718 and Califoria Form 3500 and receive our determination letters recognizing exemption. The forms required were straightforward and the representatives from the Internal Revenue Service and California Secretary of State's office were very helpful when I had questions. The writing and editing process for creating our Articles of Incorporation and Bylaws took some time, but was expedited by the fact that many of the SWC board members had previous experience working with those documents. Running the SWC Facebook page involved finding and posting links to relevant articles and information several times a week as well as organizing email campaigns and rallying followers to attend local meetings and events. It also led to several long message conversations with page followers who wanted to know more about where we stood on certain issues. I worked closely with Trink Praxel to schedule and create agendas for SWC working group and SWC board meetings throughout the course of the project and took over the duties of the Secretary position starting at our meeting on May $19^{\text {th }}, 2014$ (see Appendix L for my "SWC Meeting Notes"). I also attended City Council meetings, Water Commission meetings, and the first meeting of the Water Supply Advisory Committee in order to observe, network, and report back to SWC (see Appendix J for my "WSAC Meeting 3 Summary"). 
I learned many things during the process of turning SWC into a California nonprofit corporation and setting up the branding and social media infrastructure necessary to mount an effective advocacy campaign. At the meeting on May $19^{\text {th }}, 2014$, however, I was reminded of just how much more I have to learn. During Bill Tysseling's presentation on financing, in which he described the way campaign funding, political action committees, and the local political structure were shaping up for the next two years, I realized that in the next phase of the organization I will once again fill the role of a neophyte in regards to how much I have to learn about the ins and outs of the political process. This prospect is simultaneously intimidating and exciting, but it is the critical next step in attaining the goals set out at the beginning of this professional Masters project: to create an organization that will work with residents of Santa Cruz County, political leaders, anti-desalination activists, and others to help our area lead the state in water conservation and find a supplemental water supply that will keep water in our streams and rivers for endangered fish species and allow the local groundwater basin to recover. 


\section{Evaluation of Effectiveness}

The scope of work in this Professional Masters Project involved a broad range of administrative, legal, and networking activities, as well as the utilization of emerging communication technology. In the initial presentation to the Sustainable Water Coalition on December $9^{\text {th }}, 2014$, located in Appendix A, I defined the activities that the project would involve. This list included:

- Writing articles of incorporation, bylaws, mission statement, etc.

- Selecting which type of nonprofit will be most effective in accomplishing the goals set forth in the mission statement and articles of incorporation;

- Selecting a Board of Directors;

- Applying for an Employer Identification Number (EIN), nonprofit status, etc.;

- Creating and maintaining a website and social media sites;

- Setting up a bank account and funding strategy;

- Creating an outreach strategy;

- Conducting surveys to assess: the visibility of advocacy organizations in the area, the level of general knowledge about water issues in Santa Cruz, and how people receive information on this topic; and

- Creating a marketing/branding strategy and attain designs for logo, banners, website, etc. 
With the exception of the surveys, all of the activities on this list were either completed or are in the process of being completed, and the surveys will be completed after SWC decides on an official logo. The work completed during the course of this project was effective in turning the organization into a structurally sound and legally recognized nonprofit corporation in a much better position to affect change in the public policy arena. This status will be important in building name recognition and credibility within the community moving forward into the next, more public, elements of the strategic plan. 


\section{Conclusion}

The public policy-making process at the local level can involve conflicts among individuals, stakeholder groups, elected officials, advisory bodies, and administrative agencies, but that conflict is a necessary part of the process. This is because each individual comes to the table with his or her own "cultural values, beliefs, perceptions, and behaviors" (Orbach, 2014). Individuals who share similar views about particular issues form groups to advocate for a solution to the issue that meets the group's desired outcome. Interest groups such as these and administrative agencies may even have similar long-term goals, such as the creation of a sustainable community. The short-term approaches to attaining those goals, and the definition of what they consider to be 'sustainable', however, can be very different. This is the case in Santa Cruz County.

The mission of all interested parties is to find a sustainable and environmentallyand economically-feasible solution to the area's water supply issues, but each bases their approach on different scientific data, assumptions about and interpretations of that data, as well as different overarching ideologies about how public policy results from, and affects, individual and group behavior. In order for this policy-making process to produce a plan that fulfills the community's longterm mission of having a resilient and drought-proof water supply for local residents and endangered fish species, the first step is to get a consensus among stakeholder groups about the data, values, goals and objectives on which future policy decisions will be based. This is the process that the WSAC is 
currently going through to advise the City. However, once those data, values, goals and objectives are decided upon, those overarching ideologies will play an even more significant role.

Policy decisions, at their core, involve changing human behavior. The policymaking process surrounding water in Santa Cruz County involves estimating just how much the public is willing to change their water use habits versus how much they are willing to pay to avoid having to do so. This cost-benefit analysis is the main point of contention between conflicting stakeholder groups. Opponents to supplemental water supply options such as desalination and water recycling contend that the community as a whole is willing and able to make significant changes in and around their homes that will allow them to achieve maximum water- and energy-efficiency, such as installing greywater systems, hot water recirculation pumps, rain barrels, composting toilets, drought-tolerant landscaping instead of traditional lawns and gardens, and solar panels on their houses and in their businesses so that consumption levels will drop to a level where local surface and groundwater sources can sustainably provide for the demands of humans and endangered species in all climatic scenarios, and implicitly that any non-water neutral development in Santa Cruz Country is undesirable. The underlying ideology being that, despite our current water crisis, in order to be sustainable every member of our society needs to stop increases in energy use and reduce water consumption. Proponents of finding a supplemental water supply, such as SWC, contend that it is unrealistic to assume 
that every member of the community, a community that has already done much to conserve and is currently subject to mandatory rationing, is willing and able to drastically change their water use habits further and make significant structural changes to their homes on a community-wide basis in order to achieve conservation levels that would make a supplemental water supply unnecessary, and implicitly that some sustainable growth may be desirable. The underlying ideology in this case is that a sustainable solution will necessarily "involve tradeoffs between some state of the biophysical environment and some state of the human environment" (Orbach, 2014), for example, accepting a certain minimal level of entrapment and entrainment of marine organisms to ensure that there is enough water in the rivers for endangered fish populations, groundwater basins are safe from seawater intrusion, and there is still an adequate amount for human consumption. The former ideology assumes that the entire community is willing and able to engage in cost- and energy-intensive conservation technology and practices in their own homes while the latter assumes that a significant portion of the community will be willing to pay a little more for a supplemental water supply in order to maintain a certain quality of life.

Figuring out which policy approach, or blend of those approaches, is most suitable and feasible for Santa Cruz County will depend on how effective individuals, advocacy groups, elected officials, advisory bodies, and administrative agencies are at informing the public about their local water issues, and how those issues and the proposed solutions will affect each and every 
resident during, and long after, this second round of the search for a supplemental water supply.

By using this professional Masters project to turn a local advocacy group into a California nonprofit corporation and a 501(c)(4) social welfare organization, the policy process will now have a more evenly balanced representation of the interests of the broader community served by the City and the District, including the silent majority of residents in the area and the business community. The organization is poised to make an impact in the policy process at a critical time for the area's water supplies, giving local residents the information they need to make informed decisions about feasible water supply alternatives and the tradeoffs the community will have to make in order to have a resilient and sustainable water supply for humans, endangered species, and at-risk groundwater basins now and in the future. 


\section{Bibliography}

advocacy. (n.d.). Dictionary.com Unabridged. Retrieved May 13, 2014, from Dictionary.com website: http://dictionary.reference.com/browse/advocacy

Argument against measure p. (2012). Retrieved from http://www.cityofsantacruz.com/Modules/ShowDocument.aspx?documenti $\underline{d=28314}$

Brown, J. M. (2012, July 3). Desal measure heads to november ballot; group narrowly collects enough signatures to qualify. San Jose Mercury News. Retrieved from http://www.mercurynews.com/breakingnews/ci 21002062/desal-measure-heads-november-ballot-groupnarrowly-collects

Brown, J. M. (2013a, August 19). Santa cruz puts brakes on desal project. Santa Cruz Sentinel. Retrieved from http://www.santacruzsentinel.com/santacruz/ci 23896259/santa-cruzputs-brakes-desal-project? requestid $=696168$

Brown, J. M. (2013b, October 8). Santa cruz council weighs next steps for water supply. Santa Cruz Sentinel. Retrieved from http://www.santacruzsentinel.com/santacruz/ci 24270066/santa-cruzcouncil-weighs-next-steps-water-supply

bylaws. (n.d.). Dictionary.com Unabridged. Retrieved May 08, 2014, from Dictionary.com website: http://dictionary.reference.com/browse/bylaws

City of Santa Cruz, (2011). City of Santa Cruz Habitat Conservation Plan: Conservation strategy for steelhead and coho salmon. Retrieved from website:

http://www.cityofsantacruz.com/Modules/ShowDocument.aspx?documenti $\underline{d=21748}$

City of Santa Cruz (Designer). (2009a). City of Santa Cruz Municipal Utilities Service Area [Web Map]. Retrieved from http://www.cityofsantacruz.com/Modules/ShowDocument.aspx?documenti $\underline{d=6099}$

City of Santa Cruz. (2009b). Welcome to the water department. Retrieved from http://www.cityofsantacruz.com/index.aspx?page=54 
City of Santa Cruz and Soquel Creek Water District, (2010). Water Supply Planning for City of Santa Cruz Water Department. Retrieved from website: http://scwd2desal.org/documents/Fact Sheets/Fact WaterSupplyPlan SC Final2Lo.pdf

City of Santa Cruz and Soquel Creek Water District, (2013). Proposed scwd2 regional seawater desalination project community guide. Retrieved from scwd2 Regional Seawater Desalination Project website: http://www.scwd2desal.org/documents/Draft EIR/SCWD2 Community G uide 05.13.13 web.pdf

City of Santa Cruz Water Department, Soquel Creek Water District, (2013). Proposed scwd2 regional seawater desalination project draft environmental impact report (SCH\# 2010112038 ). Retrieved from URS website: http://www.scwd2desal.org/Page-EIR Docs.php

City of Santa Cruz Voter Approval for Desalination Facility, Measure P (November 2012). Ballotpedia. Retrieved April 29, 2014, from http://ballotpedia.org/City of Santa Cruz Voter Approval for Desalinatio n Facility, Measure P (November 2012)

Committee on Advancing Desalination Technology, National Research Council, (2008). Desalination: A National Perspective. Retrieved from National Academies Press website: http://www.nap.edu/openbook.php?record id=12184\&page=R1

League of Women Voters of California Education Fund. (2005, October 11). Measure b-2005: Siting of sewer and wastewater facilities los osos community services district. Retrieved from http://www.smartvoter.org/2005/09/27/ca/slo/meas/B-2005/

Lobbying under the insubstantial part test. (n.d.). Retrieved from http://bolderadvocacy.org/wpcontent/uploads/2012/11/Lobbying under the insubstantial part test.pdf

Mehta, N. (2009). Nonprofits and lobbying: Yes, they can! Business Law Today, 18(4), Retrieved from http://apps.americanbar.org/buslaw/blt/2009-03$\underline{04 / m e h t a . s h t m l}$ 
National Oceanographic and Atmospheric Administration, General Counsel. (2001). Endangered species act penalty schedule. Retrieved from website: http://www.gc.noaa.gov/schedules/6ESA/EnadangeredSpeciesAct.pdf

Orbach, M. A. (2012). The unquenchable thirst: Growth and desalinization in california. Unpublished manuscript, City and Regional Planning Department, California Polytechnic State University, San Luis Obispo, C.A.

Orbach, M. K. (2014). A brief essay on the nature of (and in) environmental policy. Journal for Environmental Studies and Sciences, doi: 10.1007/s13412-014-0170-3

Pierce, J. (2013, December 17). A history of santa cruz's desal fight. Retrieved from http://www.santacruz.com/2013/12/17/a history of santa cruzs desal fig $\underline{\mathrm{ht} 1 / /}$

Reddy, K. V., \& Ghaffour, N. (2007). Overview of the cost of desalinated water and costing methodologies. Desalination, 205, 340-353. Retrieved from http://www.desline.com/articoli/8151.pdf

San Luis Obispo County, Department of Public Works. (2008). Draft environmental impact report county of san luis obispo los osos wastewater project (lowwp) (2007121034). Retrieved from Michael Brandman Associates website:

http://www.slocounty.ca.gov/Assets/PW/LOWWP/Draft EIR/ Los Osos DEIR Assembled.pdf

Santa Cruz City Water Department (2012). History of the Santa Cruz City Water Department. [ONLINE] Available at:

http://www.santacruzpl.org/history/articles/157/. [Last Accessed 2/16/14].

scwd ${ }^{2}$ Desalination Program. (2008). Retrieved from http://www.scwd2desal.org/

scwd2 Desalination Program. (2012). Energy and greenhouse gas emissions. Retrieved from http://scwd2desal.org/Page-Energy.php

scwd2 Desalination Program. (2013). Proposed scwd2 regional seawater desalination project community guide. Retrieved from City of Santa Cruz 
and Soquel Creek Water District website:

http://www.scwd2desal.org/documents/Draft EIR/SCWD2 Community G uide 05.13.13 web.pdf

Soquel Creek Water District. (Designer). (2013). District Map [Web Map]. Retrieved from http://www.soquelcreekwater.org/content/district-map

Soquel Creek Water District, (2008). Fact sheet. Retrieved from website: http://soquelcreekwater.org/About-District/district-fact-sheet.pdf

Soquel Creek Water District. (2014a, May). Soquel creek water district news and updates. Retrieved from http://us5.campaign-

archive $1 . \mathrm{com} / \mathrm{u} \mathrm{u}=6 \mathrm{ccd} 1 \mathrm{~d} 0 \mathrm{c} 779 \mathrm{a} 50885 \mathrm{a} 425 \mathrm{c} 487 \& \mathrm{id}=\mathrm{f} 57492109 \mathrm{c} \& \mathrm{e}=\mathrm{f} 137$ $\underline{2141 \mathrm{~d} 7}$

Soquel Creek Water District, (2014b). Soquel creek water district conducts exploratory discussions on back-up water supply options. Retrieved from website:

http://www.soquelcreekwater.org/sites/default/files/handout exploratory di scussions web.pdf

Taxpayers Watch v. Los Osos Community Services District. CV 05-1012. (2005). Retrieved from San Luis Obispo Superior Court.

URS. City of Santa Cruz Water Department, Soquel Creek Water District, (2013). Draft eir public review summary report. Retrieved from website: http://www.scwd2desal.org/documents/Draft EIR/Public Comment Summary Report/scwd2 PublicReviewSummary FINAL(revised).pdf

U.S. Fish and Wildlife Service, Endangered Species Program. (2011). Habitat conservation plans under the endangered species act. Retrieved from website: http://www.fws.gov/endangered/esa-library/pdf/hcp.pdf

Water Supply Advisory Committee, (2014). Water supply advisory committee preliminary framework. Retrieved from City of Santa Cruz website: http://www.cityofsantacruz.com/Modules/ShowDocument.aspx?documenti $\underline{\mathrm{d}=35392}$ 


\section{Appendices}

\section{Appendix A: Presentation to Sustainable Water Coalition}

The Time is Now: Taking the Sustainable Water Coalition to the Next Level
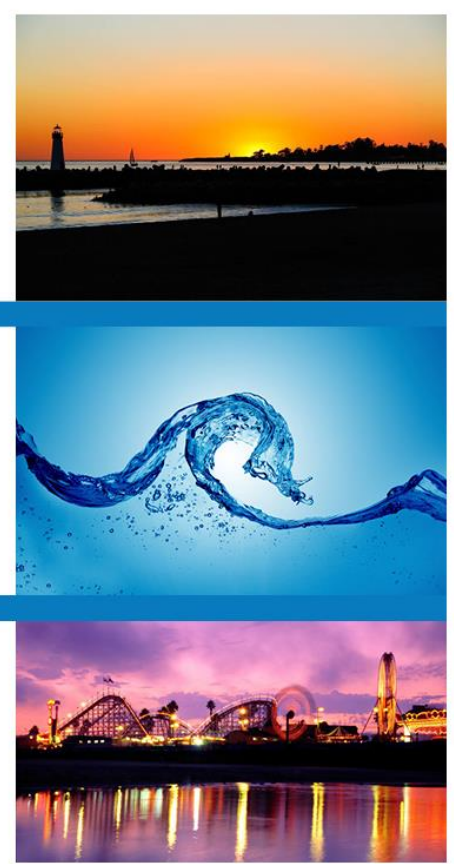

\section{Who am I?}

My name is Matt Orbach.

- Born in Santa Cruz in 1979

- Raised in coastal North Carolina

- Graduated with a B.A. in Literature from U.C. Santa Cruz in 2003

- TEFL Volunteer in the Peace Corps in Ukraine

- Crow's Nest employee for $10+$ years

- Environmental impact assessment experience at Impact Assessment, Inc.

- Student in the Master of City and Regional Planning program at the California Polytechnic State University, San Luis Obispo

Why am I qualified?

- Extensive reading on water in the American Southwest

- Familiar with social, economic, and environment issues in Santa Cruz County

- Santa Cruz specific research and term papers

- "The Unquenchable Thirst: Growth and Desalinization in California"

"Sharing a Finite Resource: 'The City of Santa Cruz Habitat Conservation Plan, Conservation Plan for Steelhead and Coho Salmon"

- Summer job/internship with the Soquel Creek Water District

- SeeWaterSC Facebook community

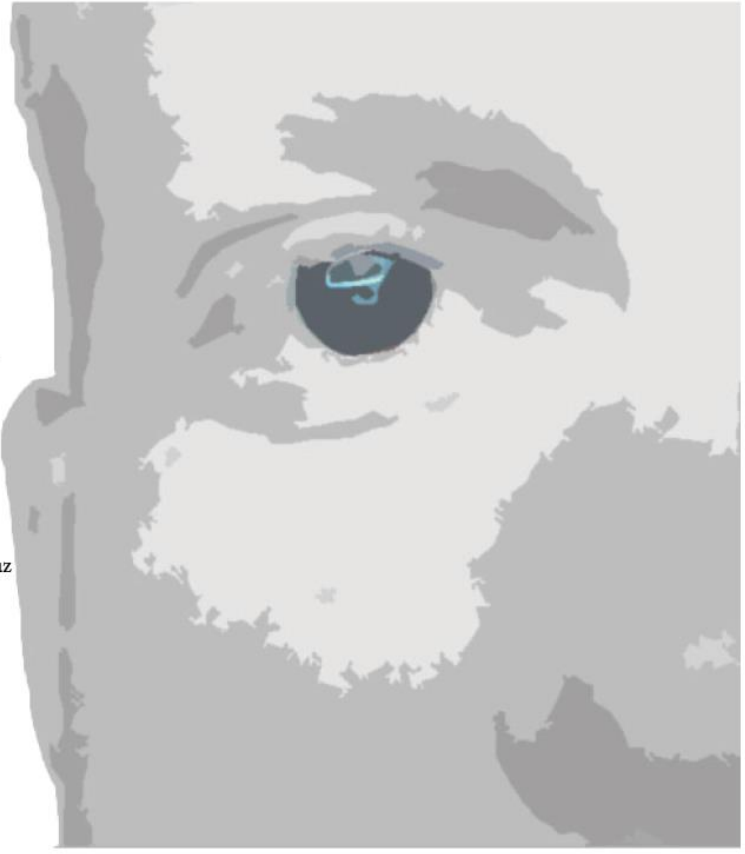




\section{Why are we here?}

1. We care about the future of Santa Cruz County

2. We are cognizant of the precarious situation we are in as a county when it comes to water supplies

3. We acknowledge that the physical, social, and economic vitality of the area depend upon the availability of a reliable and drought-proo water supply

4. We are realistic about just how much more water can be conserved through additional conservation measures, as well as the challenges that are associated with trying to do more with existing surface and groundwater supplies

5. We support the work that the City, District, and scwd2 Desalination Task Force have done up to this point, and believe that it was done in the open, transparent, and public input intensive way required by the CEQA process
6. We have watched vocal minorities have undue influence over the public policy process

7. We feel that there are many people in the community who do support the work of the City, District, and scwd2, but are either afraid or unwilling to voice their support when everything in the local media seems to be supporting the anti-desal position

8. We believe that there are even more people who would support the work of the City, District, and scwd 2 if they had accurate information about the water situation in the county

9. We believe that, with a better understanding of the current water situation and the options available, the public will make the right choice when a final supplemental water supply choice is put on the ballot in a general election

10. We can create an organization focused on stewardship, education, and advocacy that can adequately inform the public about this issue and raise support for whatever supplemental water supply projects the City and District end up pursuing after the 'reset' process

\section{What Can We Do?}

\section{The Question:}

Can a nonprofit deliver information to the voting public more effectively than the scwd2 Desalination Task Force about the need for a supplemental water supply in the immediate future? To answer this question, as well as fulfill the requirements of my professional Masters project, I am starting a nonprofit dedicated to the stewardship of wate resources, education about water issues, and advocacy for feasible water supply options in Santa Cruz, California.

\section{What it will involve:}

- Selecting which type of nonprofit will be most effective in accomplishing the goals set forth in the mission statement and articles of incorporation

- Writing articles of incorporation, bylaws, mission statement, etc.

- Selecting a Board of Directors

- Applying for an Employer Identification Number (EIN), nonprofit status, etc.

- Creating and maintaining a website and social media sites

- Setting up a bank account and funding strategy

- Creating an outreach strategy

- Conducting surveys to assess: the visibility of advocacy organizations in the area, the level of general knowledge about water issues in Santa Cruz, and how people receive information on this topic

- Creating a marketing/branding strategy and attain designs for logo, banners, website, etc.

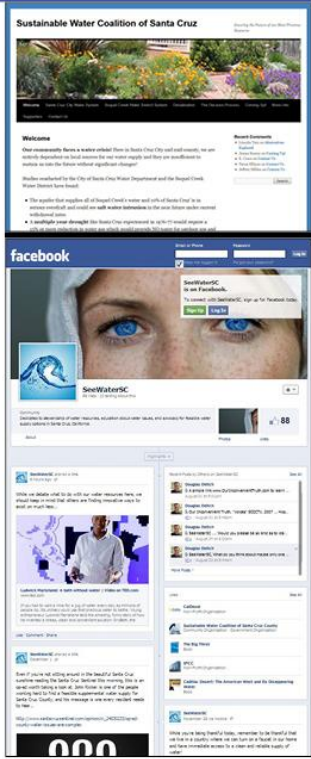




\section{Why the Sustainable Water Coalition?}

- Despite its inaction during the events of this summer and fall, the Sustainable

Water Coalition is still viewed as a forward-thinking advocate of sustainable water policy

- The board of directors of the Sustainable Water Coalition are influential members of the community

- The Sustainable Water Coalition has no formal organizational structure, and could benefit greatly from an official 501(c) IRS designation

- Board members would maintain control of the organization during this process as well as after it is complete

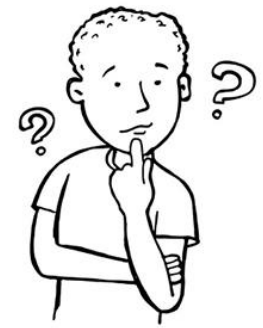

\section{Why Me?}

- I am passionate, educated, motivated, well-spoken, and very well informed about the water situation in Santa Cruz

- I am relatively unknown in the Santa Cruz political scene

- I will be working on a timeline, so the work will be completed by specified dates

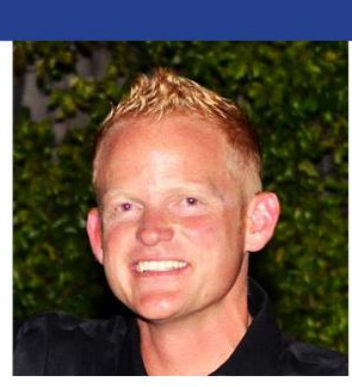

\section{Should We Proceed...}

\section{Initial Questions:}

- What nonprofit organizational structure will work best for accomplishing the goals of this group: 501 (c) 3,501 (c) 4 , or nonprofit unincorporated association?

- Do we want to go forward as the Sustainable Water Coalition? Gary Patton has a Community Water Coalition, which could make name recognition and branding difficult. In addition, the name already has negative connotations to many in the anti-desal community and possibly the public due to print and public meeting comments speculating about the goals of the organization. Settling on the name of the organization must be be decided before any IRS paperwork can be filed.

- Can you commit to working within the time constraints of my program? This project will span the next two quarters and conclude in May. The work outlined in my prospectus must be completed within this timeframe, but the organization will continue on after that.

- How many people on the current board are willing to be publicly affiliated with this organization? Once this organization receives its IRS designation, the names of the board will have to be made public. Commitment to this will require accepting a certain level of public scrutiny.
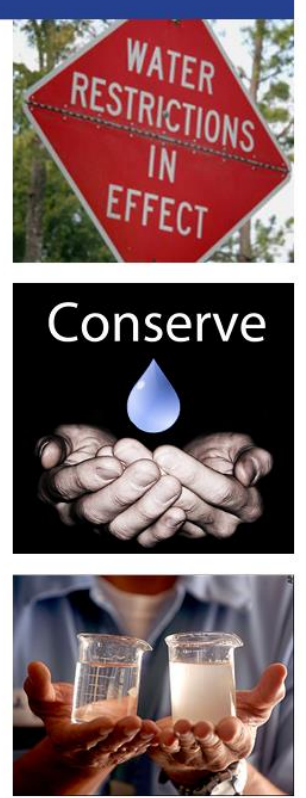


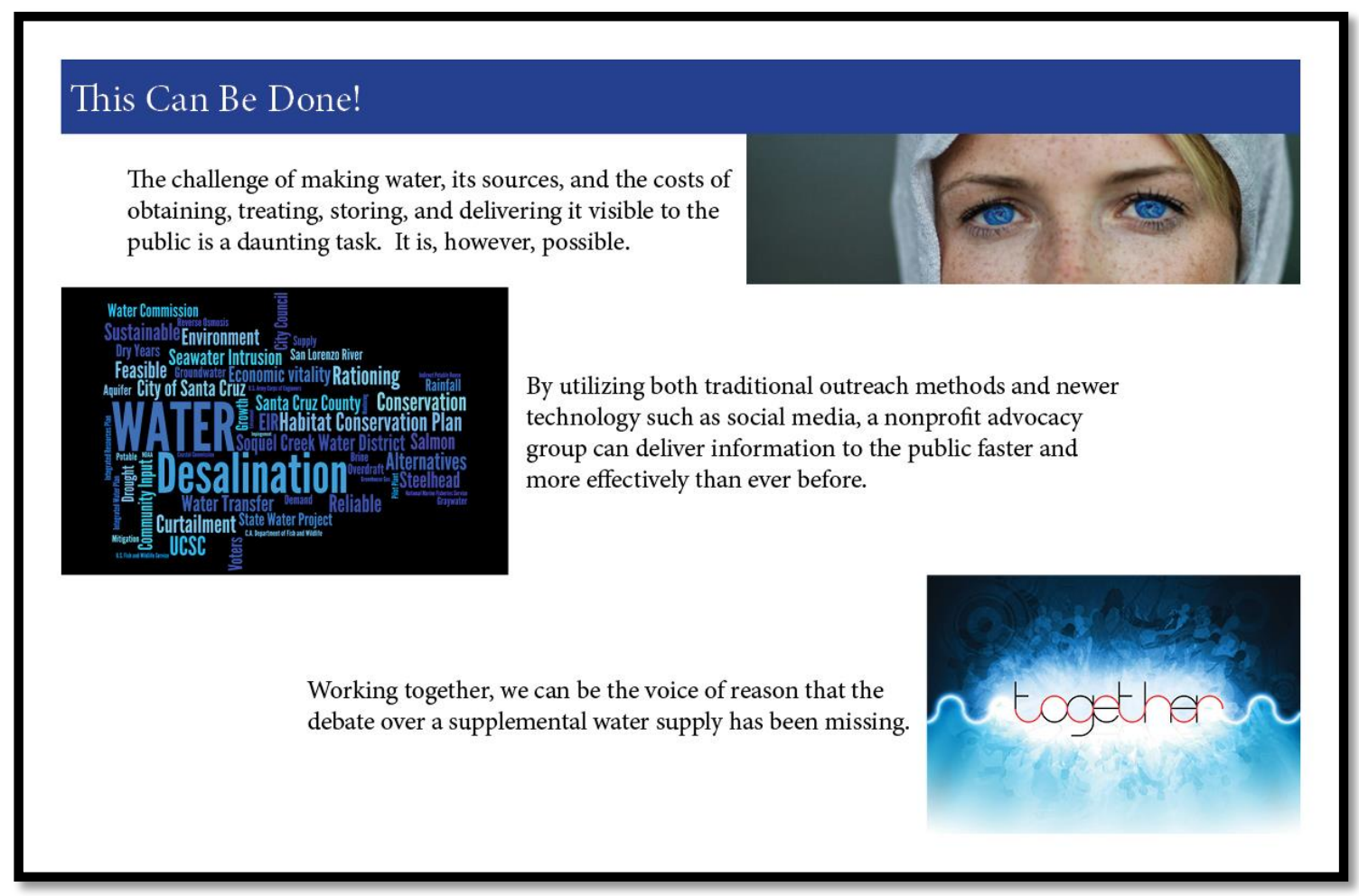




\section{Appendix B: Articles of Incorporation}

\section{5}

\section{I (c)(4) Articles of Incorporation Sustainable Water Coalition, Inc.}

$6 m^{n}$

FILED

Secrotary of State $\zeta / M$ State of California

MAR 252014

We, the undersigned natural persons, of the age of twenty-one years or more, acting as

ice incorporators of a corporation pursuant to the California Code - Division 2: NONPROFIT CORPORATION LAW, do adopt the following Articles of Incorporation:

\section{ARTICLE I. CORPORATE NAME}

The name of this corporation is SUSTAINABLE WATER COALITION, INC.

\section{ARTICLE 2. CORPORATE PURPOSE}

a. This corporation is a nonprofit Public Benefit Corporationand is not organized for the private gain of any person. It is organized under the Nonprofit Public Benefit Corporation Law for public purposes.

b. The specific purpose of this corporation is to provide (I) stewardship of surface and groundwater resources in Santa Cruz County, (2) educational activities focusing on the status of water resources in Santa Cruz County, options for supplemental water supplies, conservation, and links between water quantity and the local economy, (3) advocacy for best conservation practices, protection of local water resources, protection of the economic vitality of the area, and water supply security.

\section{ARTICLE 3. SERVICE OF PROCESS}

a. Agent's Name: Mike Rotkin

b. Agent's Street Address: 123 Liberty St., Santa Cruz, C.A. 95062

\section{ARTICLE 4. CORPORATE ADDRESSES}

a. Initial Street/Mailing Address of Corporation: 123 Liberty St.. Santa Cruz, C.A. 95062

\section{ARTICLE 5. ADDITIONAL STATEMENTS}

a. This corporation is organized and operated exclusively for the purposes set forth in Article 2a hereof within the meaning of Internal Revenue Code section 501 (c)(4). 


\section{5}

b. The corporation shall not participate or intervene in any political campaign on behalf of, or in opposition to, any candidate for public office to an extent that would disqualify it from tax exemption under section $50 \mathrm{I}$ (c)(4) of the Internal Revenue Code.

c. The property of this corporation is irrevocably dedicated to the purposes in Article 2a hereof and no part of the net income or assets of this corporation shall ever inure to the benefit of any director, officer or member thereof or to the benefit of any private person.

d. Upon the dissolution or winding up of this corporation, its assets remaining after payment, or provision for payment, of all debts and liabilities of this corporation shall be distributed to a nonprofit fund, foundation or corporation which is organized and operated exclusively for charitable or social welfare purposes and which has established its tax-exempt status under Internal Revenue Code section 50 I (c)(4).

\section{ARTICLE 6.DURATION}

The period of duration for this corporation shall be perpetual or until such time as the Board of Directors shall adopt a resolution recommending that the corporation be dissolved pursuant to the California Code - Division 2: NONPROFIT CORPORATION LAW.

\section{ARTICLE 7. MEMBERS}

This corporation shall have one class of members as provided in the Bylaws and pursuant to the California Code - Division 2: NONPROFIT CORPORATION LAW.

\section{ARTICLE 8. STOCK}

This corporation shall not have authority to issue capital stock.

\section{ARTICLE 9. AMENDMENTS TO THE ARTICLES OF INCORPORATION}

This corporation reserves the right to amend or repeal, by the affirmative vote of a majority of the members of its Board of Directors, any of the provisions contained in these Articles of Incorporation. 


\section{5}

\section{ARTICLE IO. BY-LAWS}

The Board of Directors shall have the power to adopt, amend or repeal the By-Laws of this corporation. The By-Laws shall govern the operation of this corporation unless any By-Law conflicts with these Articles of Incorporation, in which case the Articles of Incorporation shall be controlling.

\section{ARTICLE II. INCORPORATOR}

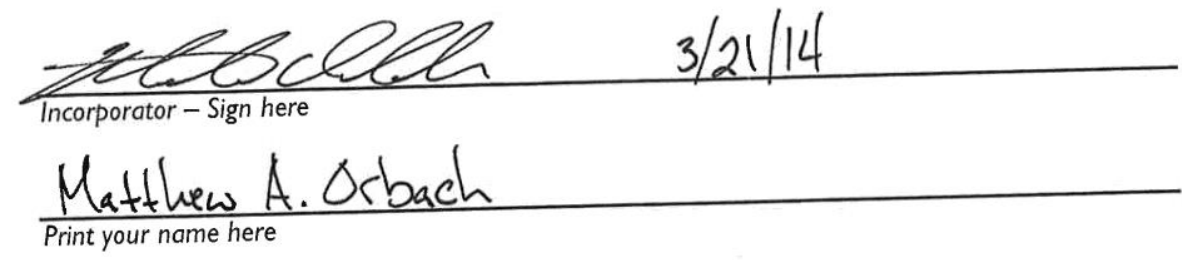




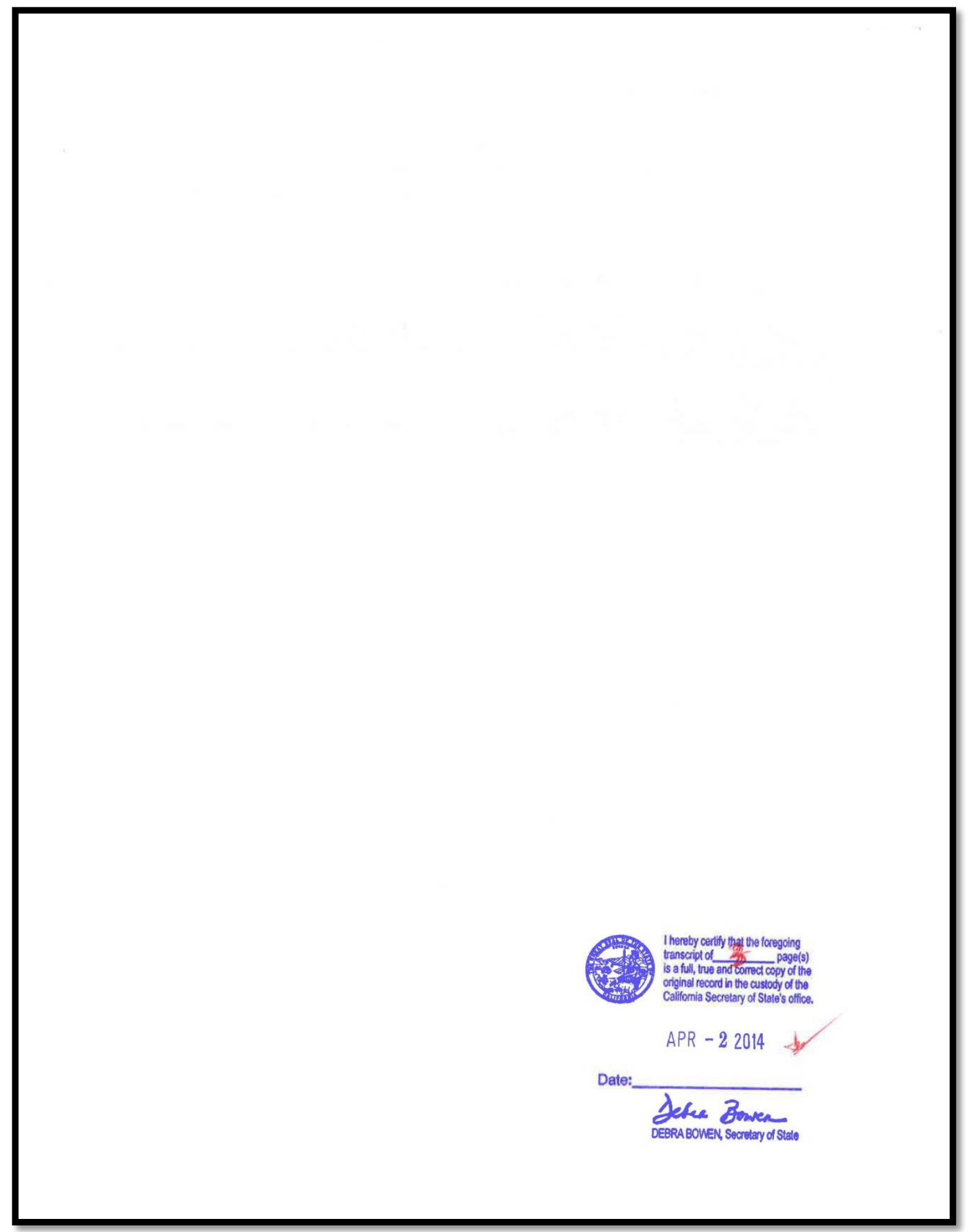




\section{Appendix C: Letters from CA SOS}

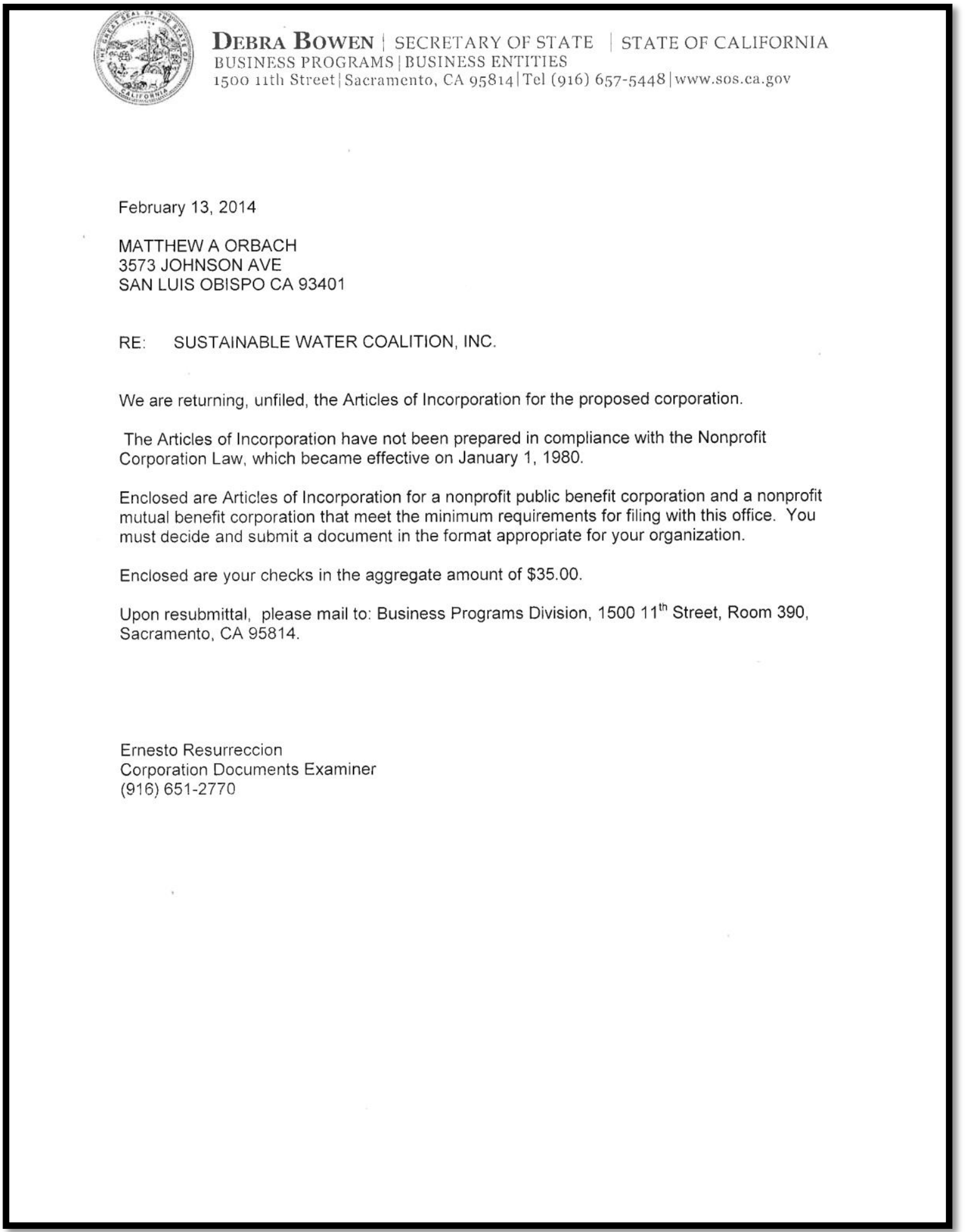


Debra Bowen | Secretary of State | STATe of California BUSINESS PROGRAMS | BUSINESS ENTITIES

1500 11th Street|Sacramento, CA 95814|Tel (916) 657-5448|www.sos.ca.gov

MARCH 14, 2014

MATHEW A ORBACH

3573 JOHNSON AVE

SAN LUIS OBISPO CA 93401

RE: SUSTAINABLE WATER COALITION, INC.

We are returning, unfiled, the Articles of Incorporation for the proposed corporation.

Pursuant to California Corporations Code sections 5120(b), the concept of "incorporator" is pertinent only if no directors have been named. Directors have been named in the Articles of Incorporation, thus any reference to "incorporator" must be deleted.

The named initial directors must sign the document at the end and then separately acknowledge their signatures as provided in California Corporations Code section 5030(b). The following signature block meets the legal requirements:

John Doe, Initial Director

Jane Doe, Initial Director

It is hereby declared that I am the person who executed this instrument which execution is my act and deed.

John Doe, Initial Director

Jane Doe, Initial Director

The Secretary of State office will no longer endorse and certify customer provided copies. However, you will receive one uncertified copy of the filed document for free. You may request the copy be certified for an additional $\$ 5.00$ certification fee. If additional copies of your filing are requested, the copy fee is $\$ 1.00$ for the first page and $\$ 0.50$ for each additional page. If you would like your additional copies certified, there is an additional $\$ 5.00$ certification fee per copy. Please do not send any copies with your original articles.

Enclosed are your checks in the aggregate amount of $\$ 35$.

Upon resubmittal, please address your correspondence to the attention of the undersigned with reference to the above date and mail to: Business Programs Division, $150011^{\text {th }}$ Street, Room 390, Sacramento, CA 95814.

Christine Baccari

Corporation Documents Examiner

(916) $651-6472$ 


\section{Appendix D: Bylaws}

\section{RESOLUTION TO RATIFY THE BYLAWS FOR SUSTAINABLE WATER COALITION, INC.}

WHEREAS, the Board of Directors have circulated, discussed, and amended draft Bylaws and a final version has been returned for ratification; and

WHEREAS, the Bylaws on record for Sustainable Water Coalition, Inc. have not been signed;

BE IT THEREFORE RESOLVED, that the Board of Directors do hereby ratify these Bylaws as the official corporation Bylaws on record.

The undersigned hereby certifies that he/she is the duly elected and qualified Secretary for a corporation duly formed pursuant to the laws of the state of California, and that the foregoing is a true record of a resolution duly adopted at a meeting of the Board of Directors and that said meeting was held in accordance with state law and the Bylaws of the above-named Corporation on May /9, 2014, and that said resolution is now in full force and effect without modification or rescission.

As witness, I have executed my name as Secretary this day of 2014.

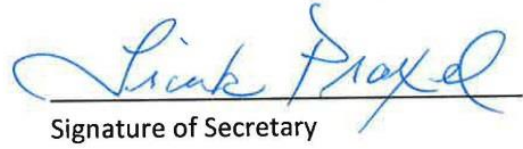

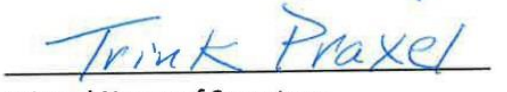

Printed Name of Secretary 


\section{Bylaws of the Sustainable Water Coalition}

I. NAME

The name of the organization is the SUSTAINABLE WATER COALITION (hereinafter referred to as "SWC").

II. PURPOSE

The purpose of the SWC is to promote stewardship of, education about, and advocacy for the responsible use of water resources in Santa Cruz County. The SWC shall be a nonprofit board-only organization.

\section{MEETINGS}

A. A minimum of one regular meeting shall be held each year, date and place to be set by the Board.

B. Business may be transacted at any regular meeting.

C. Meetings shall not be open to the public.

D. Special meetings shall be called by the Chair of the Board of Directors or any two members of the Board. Three days written notice, paper and/or electronic, shall be given to all Board Members. Such notice shall state the matter to come before the SWC.

E. A simple majority of present Board Members voting at a meeting, a quorum being present, shall suffice for the transaction of ordinary business, except as otherwise restricted herein.

\section{OFFICERS/BOARD OF DIRECTORS}

A. The Officers of The Society shall be the President, Vice President, Secretary, and Treasurer. The President shall not also serve as Treasurer.

B. The Board of Directors shall be made up of The Officers and up to five additional members. The total number of Board Members shall be an odd number between five and nine.

C. The President shall serve as Chairman of the Board.

D. Officers shall be members of the Board.

E. The term of each Board Member shall be three years, and the term of each Officer shall be one year, commencing February 1 of the year of the election.

1 
F. There shall be no limit on the number of consecutive terms Officers can serve.

G. There shall be no limit on the number of consecutive terms Board Members can serve.

H. Duties of the Officers and Board Members shall be determined by the Board.

I. Board Members shall each have one vote.

J. A simple majority of Board Members voting, a quorum being present, shall suffice for transaction of ordinary business, except as otherwise restricted herein.

K. Special meetings of the Board may be called by the President or at the request of any two members of the Board. All members of the Board must receive actual notice of the time, place, and issue to come before the Special Meeting not less than forty-eight hours in advance, and no other matter may be determined at that Special Meeting. Members of the Board who are not able to attend may exercise their vote on the named issue in writing, signed and delivered to the President before the question is voted and delivered to the President before the question is voted.

L. The Board shall, among other powers:

a. Approve an annual budget in advance of commitment for the expenses being proposed.

b. Approve all programs and projects bearing the name of the SWC.

c. Fill vacancies on the Board, by a majority vote of the remaining members of the Board.

d. Approve the President's appointment of chairs and committees.

e. Have the authority to hire any employee or contractor of the SWC as may be necessary.

\section{ELECTION OF OFFICERS AND BOARD MEMBERS}

A. A Nominating Committee consisting of three Board Members of the SWC shall be appointed by the President with the approval of a majority of the Board. Members of the Nominating Committee shall not nominate themselves for office in the current election, but may be nominated by members of the Board not on the Nominating Committee.

B. The Nominating Committee shall select a slate of candidates, which need not be limited to one candidate per Board Member/Officer position to be filled, and shall present that slate to the Board on or before the next meeting. At that time, the board may make additional nominations.

C. The Board shall approve the slate as presented/amended.

D. The election of Board Members and Officers shall take place at the SWC meeting in February. At that event, the vote may be taken by hand count or by ballot. 
Absentee voting shall be permitted by mail with the deadline being seven days prior to the date of the actual election.

E. Candidates receiving the most votes shall be elected. In case of a tie, the Nominating Committee, by lot, shall select the winner.

F. A Board Member may resign by submitting a written resignation to the Board, which will become effective when accepted by the Board.

G. A Board Member may be suspended for cause by two-thirds vote of the Board. The Board Member shall be notified in writing of the Board's action, and may appeal the suspension at the next meeting of the Board. If the suspension is sustained by a two-thirds vote of the remaining Board Members, the Board member shall be removed as of that date.

H. Upon removal or resignation of a Board Member, the Board shall fill the vacancy if needed to meet the requirements of Board composition as herein described. If the Board Member was serving as an Officer, the Board shall elect a new officer.

\section{COMMITTEES}

A. Special Committees, which may be committees of one, may be empowered by the Board to conduct one or more of the SWC's programs or functions.

B. Chairpersons of Special Committees are appointed by the President, subject to the approval of the Board. Chairpersons are authorized to approve or disapprove actions of the committee, and shall retain ultimate responsibility for all activities of the committee.

C. The organization, operation, and membership of any committee shall be determined by the Chairperson of the committee.

D. The Committee Chairpersons are required to make reports concerning their committees at regular Board Meetings.

E. The Committee is considered dissolved once the objective of its organization has been achieved, or upon action by the Board.

\section{FINANCIAL AND FISCAL AFFAIRS}

A. The funds of the SWC shall be kept in a checking account to the extent needed for current operation. Additional funds may be kept in interest-bearing accounts selected by the Treasurer with approval of the Board.

B. No monies may be disbursed from SWC accounts except on signature of the Treasurer. In the absence of the Treasurer, the President shall be empowered to 
disburse funds. The Board may also empower an employee of the SWC to disburse funds.

C. An audit of the books, accounts, and assets of the SWC shall be made at the direction of the Board.

D. The Board may approve a financial report without an audit.

E. No contract or expense in excess of one hundred dollars, or any other obligation of SWC funds, facilities, equipment, or reputation shall be made or undertaken without approval. Approval shall be obtained from the Treasurer, or in his/her absence, from the President, Vice President, or Secretary.

F. Compensation for any goods or services supplied to the SWC by a member, Board Member, or employee/contractor shall require written receipt and prior approval of the Board either as a budgeted expense or as a separately approved expense.

G. The budget constitutes approval of related expenditures.

\section{USE OF THE NAME OF THE SUSTAINABLE WATER COALITION}

The SWC shall not allow the use of its name in connection with any activity not under its direct control without prior approval of the Board. No Officer, Board Member, or employee/contractor of the SWC may claim to represent the SWC in any matter unless empowered to do so under these Bylaws.

\section{AMENDMENT OF BYLAWS}

Amendment of the Bylaws, or any new Bylaws, may be proposed at any regular Board meeting. The proposed amendment or new Bylaws shall be read at that meeting and the proposal shall be tabled. A copy of the proposed change or addition and a dated ballot will be distributed to all Board Members. Ballots may be returned by mail, e-mail, or in person by the deadline specified on the ballot. A majority of all Board Members shall be required to adopt the amendment or new Bylaws.

\section{DISSOLUTION}

A. A proposal to dissolve the SWC must be brought before the Board by a minimum of three members of the Board. A majority of all Board Members shall be required for approval.

B. In the event of dissolution, none of the remaining assets may be distributed to, or be used for, the benefit of any Board Member. Remaining assets shall be donated to a qualified 501 (c)(3) or 501(c)(4) non-profit organization. The selection of the 
qualified organization or organizations shall be made by a majority of all Board Members. 


\section{Appendix E: EIN Letter}

\$FIII IRS DEPARTMENT OF THE TREASURY

INTERNAL REVENUE SERVICE

CINCINNATI OH 45999-0023

003538.426248 .57948 .47651 MB 0.435530

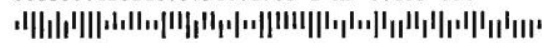

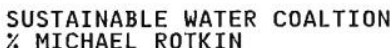

\% MICHAEL ROTKIN

123 LIBERTY ST
SANTA CRUZ CA 95060

003538

Date of this notice: 03-19-2014

Employer Identification Number: 30-0811414

Form: SS-4

Number of this notice:

CP 575 E

For assistance you may call us at: $1-800-829-4933$

IF YOU WRITE, ATTACH THE STUB OF THIS' NOTICE.

WE ASSIGNED YOU AN EMPLOYER IDENTIFICATION NUMBER

Thank you for applying for an Employer Identification Number (EIN). We assigned you EIN 30-0811414. This EIN will identify you, your business accounts, tax returns, and documents, even if you have no employees. Please keep this notice in your permanent records.

When filing tax documents, payments, and related correspondence, it is very important that you use your EIN and complete name and address exactly as shown above. Any variation may cause a delay in processing, result in incorrect information in your account, or even cause you to be assigned more than one EIN. If the information is not correct as shown above, please make the correction using the attached tear-off stub and return it to us.

ANNUAL FILING REQUIREMENTS

Most organizations with an EIN have an annual filing requirement, even if they engage in minimal or no activity.

A. If you are tax-exempt, you may be required to file one of the following returns or notices:

Form 990, Return of Organization Exempt From Income Tax

Form 990-EZ, Short Form Return of Organization Exempt From Income Tax

Form 990-PF, Return of Private Foundation

Form 990-N, e-Postcard (available online only)

Additionally, you may be required to file your annual return electronically.

If an organization required to file a Form 990, Form 990-PF, Form 990-EZ, or Form 990-N does not do so for three consecutive years, its tax-exempt status is automatically revoked as of the due date of the third return or notice.

Please refer to WWW.irs.gov/990filing for the most current information on your filing requirements. 
B. If you are not tax-exempt, you may be required to file one of the following returns:

Form 1120, U.S. Corporation Income Tax Return

Form 1041, U.S. Income Tax Return for Estates and Trusts

Form 1065, U.S. Return of Partnership Income

Please refer to Publication 1635, Understanding Your EIN, for more information about which forms you may be required to file.

APPLYING FOR TAX-EXEMPT STATUS

Receiving an EIN from the IRS is not the same thing as receiving IRS recognition of tax-exempt status. To apply for formal recognition of tax-exempt status, most organizations will need to complete either Form 1023, Application for Recognition Under Section $501(\mathrm{c})(3)$ of the Internal Revenue Code, or Form 1024, Application for applicable attachments and the required user fee to:

Internal Revenue Service
P0 Box 12192

Covington, KY 41012-0192

Publication 557, Tax Exempt Status for Your Organization, has details on the Publication 557, Tax Exempt Status for Your Organization, has details on the
application process, as well as information on returns you may need to file. ADDITIONAL INFORMATION

To obtain tax forms and publications, including those referenced in this notice, visit our Web site at WWw.irs.gov. If you do not have access to the Internet, call 1-800-829-3676 (TTY/TDD 1-800-829-4059) or visit your local IRS office.

IMPORTANT REMINDERS :

* Keep a copy of this notice in your permanent records. This notice is issued only one time and IRS will not be able to generate a duplicate copy for you. You may give a copy of this document to anyone asking for proof of your EIN.

* Use this EIN and your name exactly as they appear at the top of this notice on all your federal tax forms.

* Refer to this EIN on your tax-related correspondence and documents.

* Provide future officers of your organization with a copy of this notice.

Your name control associated with this EIN is SUST. You will need to provide this information, along with your EIN, if you file your returns electronically.

If you have questions about your EIN, you can call us at the phone number or write to us at the address shown at the top of this notice. If you write, please tear off the stub at the bottom of this notice and send it along with your letter. If you do not need to write us, do not complete and return this stub. Thank you for your cooperation. 

Your Telephone Number Best Time to Call DATE OF THIS NOTICE: 03-19-2014
EMPLOYER IDENTIFICATION NUMBER: $30-0811414$ FORM: $\quad$ SS-4

INTERNAL REVENUE SERVICE

SUSTAINABLE WATER COALTION

CINCINNATI OH 45999-0023

\% MICHAEL ROTKIN

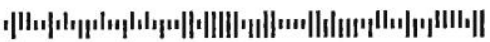

123 LIBERTY ST

SANTA CRUZ CA 95060 


\section{Appendix F: Form SI-100}

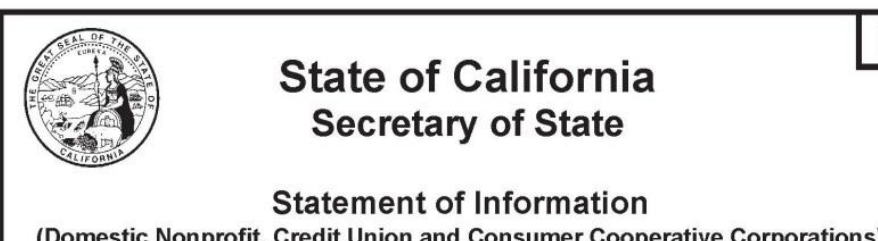

(Domestic Nonprofit, Credit Union and Consumer Cooperative Corporations)

Filing Fee: $\$ 20.00$. If this is an amendment, see instructions. IMPORTANT - READ INSTRUCTIONS BEFORE COMPLETING THIS FORM

\section{CORPORATE NAME}

SUSTAINABLE WATER COALITION, INC

\section{EY55061 \\ FILED}

In the office of the Secretary of State of the State of California

MAY-21 2014

Complete Principal Office Address (Do not abbreviate the name of the city. Item 3 cannot be a P.O. Box.)

\begin{tabular}{|c|c|c|c|}
\hline $\begin{array}{l}\text { 3. STREET ADDRESS OF PRINCIPAL OFFICE IN CALIFORNIA, IF ANY } \\
\text { 123 LIBERTY ST., SANTA CRUZ, CA } 95062\end{array}$ & CITY & STATE & ZIP CODE \\
\hline AILING ADDRESS OF THE CORPO & CITY & TATE & IP CODE \\
\hline
\end{tabular}

Names and Complete Addresses of the Following Officers (The corporation must list these three officers. A comparable title for the specific officer may be added; however, the preprinted titles on this form must not be altered.)

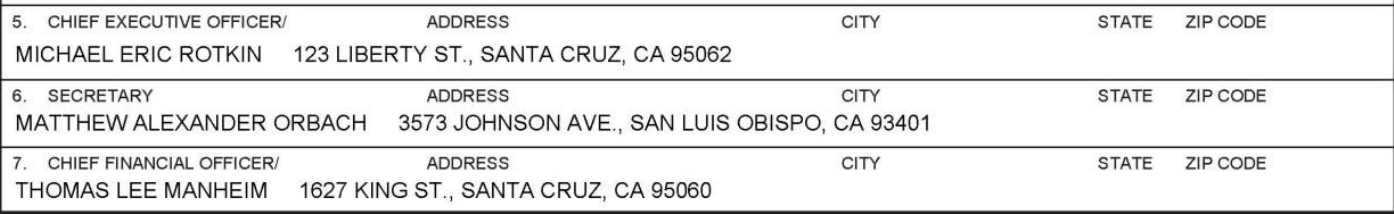

Agent for Service of Process If the agent is an individual, the agent must reside in California and Item 9 must be completed with a California street address, a P.O. Box address is not acceptable. If the agent is another corporation, the agent must have on file with the California Secretary of State a certificate pursuant to California Corporations Code section 1505 and Item 9 must be left blank.

8. NAME OF AGENT FOR SERVICE OF PROCESS

MICHAEL ERIC ROTKIN

9. STREET ADDRESS OF AGENT FOR SERVICE OF PROCESS IN CALIFORNIA, IF AN INDIVIDUAL CITY

123 LIBERTY ST., SANTA CRUZ, CA 95062

Common Interest Developments

10. Check here if the corporation is an association formed to manage a common interest development under the Davis-Stirling Common Interest Development Act, (California Civil Code section 4000, et seq.) or under the Commercial and Industrial Common Interest Development Act, (California Civil Code section 6500, et seq.). The corporation must file a Statement by Common Interest Development Association (Form SI-CID) as required by California Civil Code sections 5405(a) and 6760(a). Please see instructions on the reverse side of this form.

11. THE INFORMATION CONTAINED HEREIN IS TRUE AND CORRECT.

\begin{tabular}{|c|c|c|c|}
\hline $05 / 21 / 2014$ & MATTHEW ALEXANDER ORBACH & MR. & \\
\hline DATE & TYPE/PRINT NAME OF PERSON COMPLETING FORM & TITLE & SIGNATURE \\
\hline 0 (REV 01/2014 & & & OVED BY SECRETARY OF STATE \\
\hline
\end{tabular}




\section{Appendix G: Facebook Promoting Report}

\section{Facebook Promoting Report}

There are two paid options Facebook gives you for "Growing Your Audience". You can "Promote Your Page" or "Boost Your Posts". This report will go over what each of those options entails as far as targeting, cost, and effectiveness.

\section{Promoting Your Page}

Promoting a Facebook page involves creating an advertisement and paying a daily fee to have them circulate it. The goal of promoting is to increase the number of followers of your page. A small amount of text and images can be included.

Targeting:

Promotions can be targeted to a specific audience. Variables for targeting include: location, interests, age, and gender. Using these, we can pinpoint different demographics within Santa Cruz that we would like to reach.

Budget:

Facebook has several different tiers of budget options, ranging from $\$ 5-20$ per day, and can be circulated for a set period of time or continuously until an administrator chooses to stop it.

When/Why:

Promoting an advertisement for our page serves to increase name recognition for SWC as well as build a larger Facebook following. Advertisements can also include the names of friends of potential followers who have 'liked' our page. Promoting advertisements

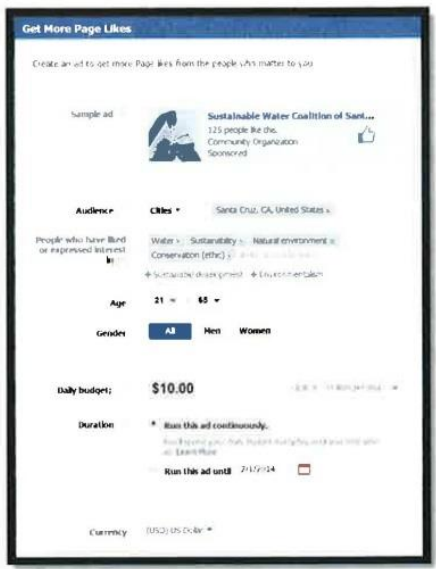
periodically is a good way to maintain visibility.

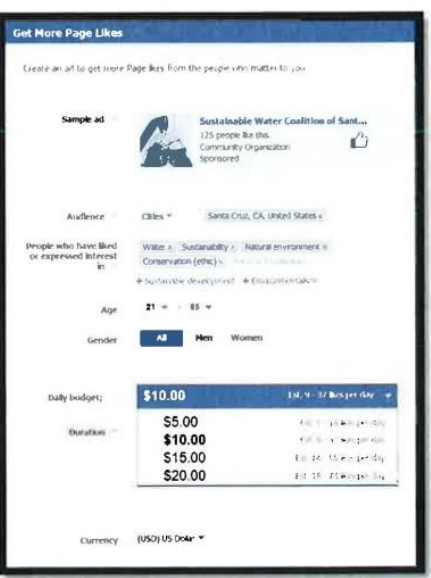




\section{Boosting Your Posts}

Boosting posts is designed to increase the visibility of posts on your Facebook page, either in the news feeds of current followers or other Facebook users. For current followers it keeps the post higher in the news feed, increasing the likelihood that they see it. For others it shows up as a sponsored advertisement. The primary goal of this is to share specific articles, messages, or events of particular importance with Facebook users. This could lead to more page 'likes', but is more suited to spreading specific information.

\section{Targeting:}

The Boosting option allows you to target either current followers of your page and their friends or people you choose through targeting. It allows for the same demographic targeting variables that Promoting and advertisement does (location, interests, age, and gender).

Budget:

Facebook offers several budget options for Boosting a post, ranging from $\$ 15-600$, but also providing a "Choose Your Own" option. Each price point has an estimated reach, illustrating how many people will see the post. This number varies depending on how specific you are with your targeting. Boosted posts usually run for one day from when they're created.

When/Why:

Boosting a post can be valuable for sharing important information with Facebook users who may not be interested enough in your cause to follow your page.

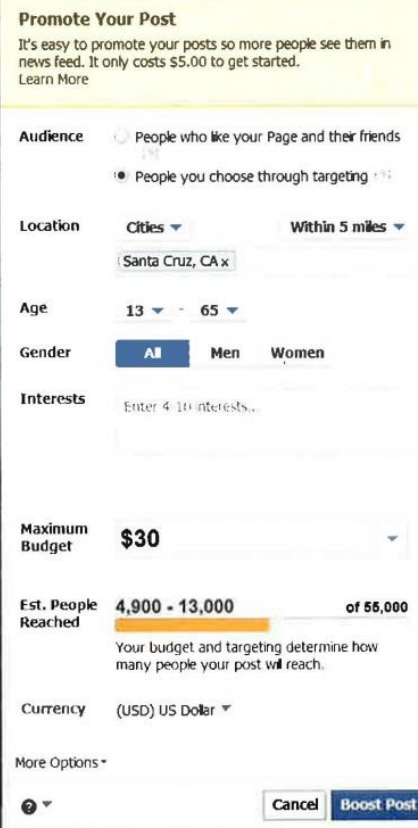

\begin{tabular}{|c|c|c|}
\hline $\begin{array}{c}\text { Maximum } \\
\text { Burlget }\end{array}$ & $\$ 30$ & F \\
\hline$\$ 15$ & & Est. Reach 2,600 - 6,800 \\
\hline$\$ 30$ & & Est: Reach 4,900-13,000 \\
\hline$\$ 40$ & & Est. Reach 6,300 - 17,000 \\
\hline$\$ 60$ & & Est. Reach 9,100 - 24,000 \\
\hline$\$ 100$ & & Est. Reach $13,000-35,000$ \\
\hline$\$ 150$ & & Est. Reach $18,000-47,000$ \\
\hline$\$ 200$ & & Est. Reach 22,000-55,000 \\
\hline$\$ 400$ & & Est. Reach $30,000 \cdot 55,000$ \\
\hline$\$ 600$ & & Est. Resch 30,000 - 55,000 \\
\hline \multicolumn{3}{|c|}{ Choose Your Own } \\
\hline
\end{tabular}


This could be used to spark interest in a particularly hard-hitting letter to the editor, get a targeted message out to broad audience, or increase turnout for a meeting or election.

\section{Summary}

Both "Promoting Your Page" and "Boosting Your Posts" can be useful in maintaining visibility in the Facebook community and finding new followers. We should develop and promote several simple and eye-catching advertisements, as well as boost several important posts, to see how effective they can be for us. 
Appendix H: Logo Examples

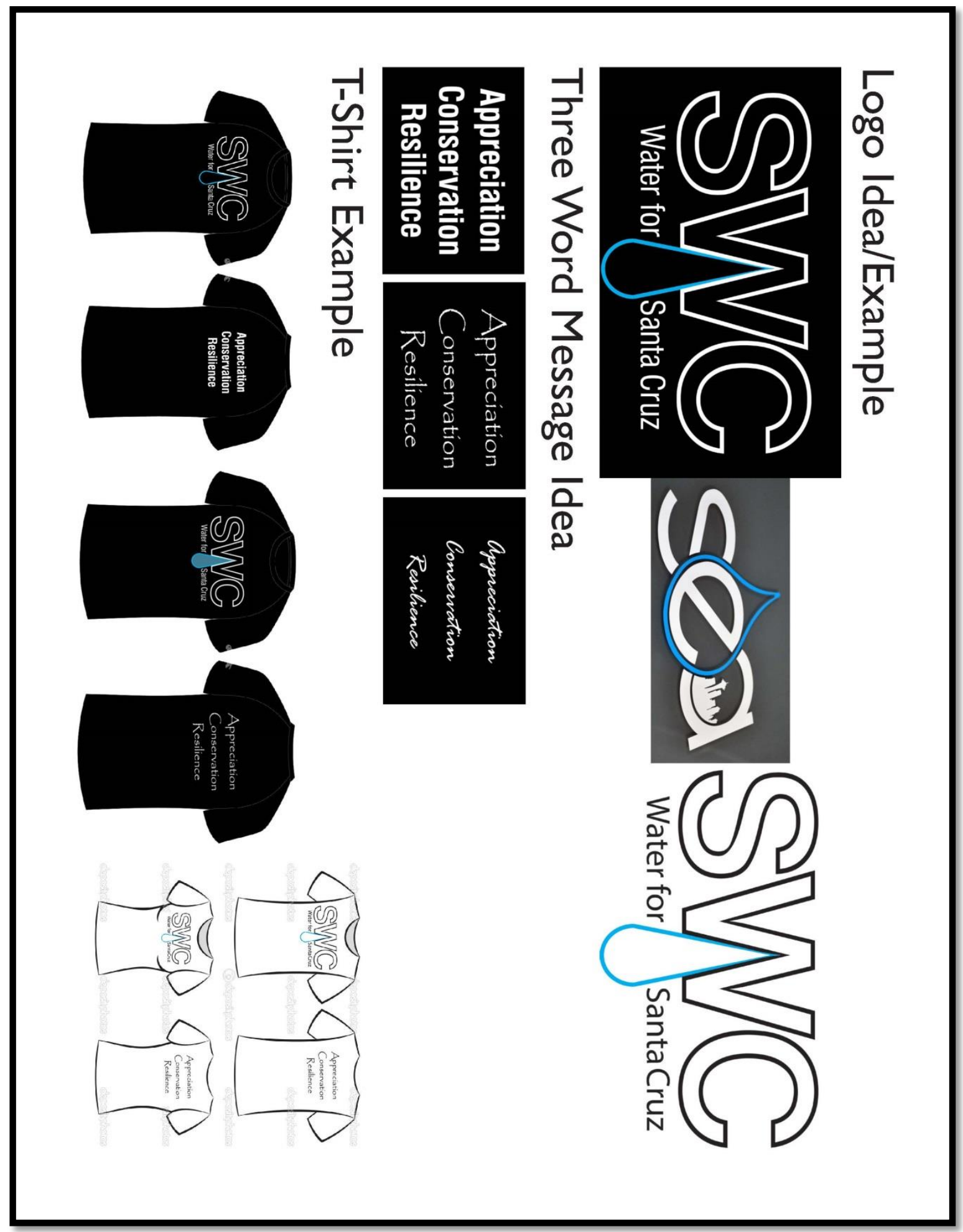




\section{Appendix I: Official Stratus Email and Stratus Email for Facebook}

April 8th, 2014

Dear Council,

The Sustainable Water Coalition supports the City's decision to hire Stratus Consulting to assist the Water Supply Advisory Committee (WSAC). Stratus is a well-qualified non-partisan consultant that has already worked with the City for more than a year on economic analysis, and will provide excellent comprehensive research and analysis for the WSAC. Additionally, we support their working with Kennedy-Jenks as technical counsel because they have the most in-depth technical knowledge of the alternatives that have already been explored in the Draft EIR, and can therefore provide invaluable assistance to Stratus.

The WSAC process is supposed to be an iterative review and consideration of information with all alternatives, including desalination, on the table. Iterative means repetitive, and should include that which has already been considered as well as any possible new information. If we are going to have a truly honest and informed process in which all alternatives are considered, then Stratus Consulting is a great choice.

Additionally, we believe that the task of selecting of a consulting firm should remain with the City, not the WSAC members, who have little to no experience selecting qualified proposals and are much more likely to select a firm that they feel aligns more closely with their individual opinions. With the current drought conditions and costly mandatory rationing already being implemented, every delay in selecting a qualified consulting firm makes us more vulnerable to water shortages and the social, economic, and environmental consequences that go with them.

Sincerely,

Matt Orbach

Board Member

Sustainable Water Coalition 


\section{Dear Council,}

I support the City's decision to hire Stratus Consulting to assist the Water Supply Advisory Committee (WSAC). Stratus is a well-qualified non-partisan consultant that has already worked with the City for more than a year on economic analysis, and will provide excellent comprehensive research and analysis for the WSAC. Additionally, I support their working with Kennedy-Jenks as technical counsel because they have the most in-depth technical knowledge of the alternatives that have already been explored in the Draft EIR, and can therefore provide invaluable assistance to Stratus.

The WSAC process is supposed to be an iterative review and consideration of information with all alternatives, including desalination, on the table. Iterative means repetitive, and should include that which has already been considered as well as any possible new information. If we are going to have a truly honest and informed process in which all alternatives are considered, then Stratus Consulting is a great choice.

Additionally, I believe that the task of selecting of a consulting firm should remain with the City, not the WSAC members, who have little to no experience selecting qualified proposals and are much more likely to select a firm that they feel aligns more closely with their individual opinions. With the current drought conditions and costly mandatory rationing already being implemented, every delay in selecting a qualified consulting firm makes us more vulnerable to water shortages and the social, economic, and environmental consequences that go with them.

Sincerely,

Your Name Here 


\section{Appendix J: WSAC Meeting 3 Summary}

\section{Water Supply Advisory Committee - Meeting \#3 Summary \\ $5-2-14$ \\ Matt Orbach}

SWC members,

I attended the WSAC meeting at the Long Marine Laboratory on Friday, May

2nd, 2014. There were 12-13 members of the public in attendance, including myself, Heidi Luckenbach, and Jerry Paul. I recognized most of the rest as regular anti-desal attendees of City Council and Water Commission meetings.

\section{$\underline{\text { Charter Triage }}$}

The agenda started with 'Charter triage', which included a discussion of the current status of the charter that had been talked about at the previous two meetings as well as the creation of a Charter Subcommittee made up of Mike Rotkin, David Baskin, and Erica Stanojevic. The Charter Subcommittee will be working on finalizing a draft of the Charter to bring back to the rest of the group to save in-session discussion time for more important topics.

$\underline{\text { Public Input }}$

The group also decided to allow for public input on an as-needed basis, leaving time for it at the beginning of meetings as well as reserving time before any important decision is to be made. Several community members were then given 
the opportunity to speak. Jerry Paul asked if it was possible to have water rights experts and/or fisheries regulators on hand at the meetings to answer any questions and have their input available for the discussions. Another person expressed a desire for more opportunities for public comment and asked to have the committee set up short-term achievable milestones.

\section{$\underline{\text { Work Plan }}$}

The facilitators then led a discussion about whether the committee would like to go with the 'Option A' or 'Option B' approach to their work plan. 'Option A' involved a linear problem solving process that several members likened to the approach the City and District took in evaluating water supply alternatives the first time. 'Option B' allowed the group to use a multiple round approach, starting with a quick review and then delving into more detail in each round as alternatives are examined, discussed, and possibly eliminated. The group was unanimous in supporting the 'Option B' approach to the work plan.

\section{Hiring a Consultant}

Then the group moved on to the most contentious topic of the day: the hiring of Stratus Consulting. Assistant City Manager Tina Shull and Santa Cruz Water Department General Manager Rosemary Menard were invited to give a summary of both the process the City used to select Stratus Consulting as well as what the role of the WSAC was going to be in the consultant selection process. Tina gave 
a brief overview of the April 8th City Council meeting and the outcome, which was that the City would hold off on the decision to hire Stratus Consulting until they received recommendations from the WSAC, but that they hoped to make a decision at their next meeting on May 13th. She made very clear, however, that the decision to hire a consultant is a Council decision in the end because it is their fiduciary duty by law and in their charter. She explained how there would be one base consulting group that would assist the WSAC, but that additional technical experts that could be added later. And she also reminded the group that the role of the WSAC is to go through an iterative process of reviewing alternatives and providing feedback to City Council.

The committee then embarked on a long discussion of the consultant selection process, their role in it, and what their options were for making recommendations to the Council. Rick Longinotti was given a chance to air his grievances about Stratus, Gary Fiske, and Kennedy-Jenks, which (I felt) were adequately addressed by both Rosemary and other members of the committee. He explicitly stated that he "didn't want to argue with Raucher about carbon offsets". Mark Mesiti-Miller gave a wonderful rebuttal, pointing out that "consultants do what you ask them to do" without bringing in their own agenda. Rosemary also gave a brief overview of her history with Bob Raucher, including multiple examples of the diverse types of water projects he and his group have worked on (giving context to the examples Rick had brought up as evidence of Raucher's bias towards desalination). Sue Holt brought up a good point about how proceeding with the 
Stratus hire might start the WSAC process with a bruised public image. Erica Stanojevic, Peter Beckmann, Doug Engfer, and Sarah Mansergh also had issues with hiring Stratus. The facilitators then went through ways in which hiring Stratus could be mitigated. Mark also proposed that the City should come to the next WSAC meeting and make a presentation about the RFQ process they went through to find Stratus, including a description of the qualifications they were searching for, a list of consultants that responded, and a list of consultants that were evaluated. In that way the committee could understand, evaluate, and (hopefully) affirm the Stratus selection.

\section{The (Not So) Grand Finale}

The end of the meeting was a little confusing. The female facilitator asked if the committee would like to make a decision on a recommendation that day or wait until the next meeting, and David Stearns was the only one to respond, saying that he would like to make the decision that day. She then proceeded to put together a list of recommendation options as if the committee had come to a consensus that a decision must be made that day, which was a bit confusing to me as well as many of the committee members. The facilitators hurriedly put together a list of recommendation options that was narrowed down to three: (1) Have the City proceed with the Stratus hire, but incorporating some of the WSAC mitigation ideas, and hire a panel of WSAC experts to help them review the Stratus work; (2) Have the City proceed with the Stratus hire independently of the WSAC and hire a panel of WSAC experts to help review the Stratus work 
(essentially creating an 'ours' and 'their' with the two consulting groups); and (3) Do not make a recommendation to the Council. There seemed to be a general consensus that option 1 was the best option, but the group was notified that staff needed the room for another function, and during the process of trying to take a vote Peter, Erica, and Sarah stated that they did not want to make a rushed decision, essentially scuttling the process.

\section{General Impressions}

- The group generally seemed rationale and logical in their discussions of the issues at hand, but some people clearly did not understand what the role of the committee in this process is (even after being told multiple times by Rosemary, Tina, and the facilitator), namely Peter, Erica, and Sarah. Those three, even more so than Rick, seem to be the ones who will be holding up this process.

- Rosemary came off as a bit defensive and frustrated at times, but Tina did a good job staying calm and collected while reminding committee members multiple times about what they could and couldn't do.

- David Baskin, Mike, Doug, and Mark seemed to be the most vocal during this meeting. 
- Mark's proposal for having someone from the City come and give a presentation about the RFQ process that ended up with the selection of Stratus is one that I believe we should go on the record supporting.

- I think that, with a little more time, a majority of the committee members would have supported recommending option number one to the Council, so it's a shame that the meeting ended the way it did. Failing to make a recommendation puts the Council right back where they were before at the April 8th meeting, so it will be interesting to see what they decide to do at the May 13th meeting. 


\section{Appendix K: "Santa Cruz puts brakes on desal”, Santa Cruz Sentinel}

http://mww.santacruzsentinel.com/santacruz/ci_23896259/santa-cruz-puts-brakes-desal-projecł\#

\section{Santa Cruz puts brakes on desal project}

By J.M. Brown Santa Cruz Sentinel Santa Cruz Sentinel

Posted:Mon Aug 19 19:43:13 MDT 2013

SantaCruzSentinel.com

SANTA CRUZ -- The city's top two officials have announced their recommendation not to pursue a vote in 2014 on a controversial seawater desalination plant and instead work with the public on other avenues for safeguarding a drought-prone water supply.

"We listened and we heard that we are certainly not in agreement, and we recognize the need to re-engage in a community involved process to evaluate our water problem," Mayor Hilary Bryant said in an interview Monday. "If nothing else, it's my job and the council's job to listen to the community."

During a 90-day period that ended Aug. 12, regulators and members of the public submitted more than 400 comments on a draft environmental impact report for the proposed facility, many of which question the need for an additional water supply and promote alternatives. That fact, paired with largely negative feedback during public hearings this summer, led officials to conclude the project likely would fail at the ballot box in June or November 2014.

"It's clear there just isn't enough consensus and understanding," City Manager Martin Bernal said in a joint interview with the mayor.

Bernal said he will draft "a community involvement plan" by the end of 2013. Meanwhile, he said ratepayers should not assume desal is dead or that the recommended delay is designed to repackage the plan to be more palatable later.

"We want to be open-minded, and desal is one option," Bernal said. "We were not relying 100 percent on desal, including new conservation and even curtailment. It was just what seemed to be a viable alternative."

Bernal's recommendation comes less than two weeks after the city's water director announced his retirement, which the desal proponent said was driven by turning 65 and not about the public tide turning on desal. The move also comes as more citizens are focused on public safety issues including several high-profile cases of violence, discarded drug needles and homelessness.

Bryant said she hoped ratepayers will get engaged in devising water supply solutions. The city has called for water restrictions three times since 2009 due to low rainfall, but customers haven't been asked how much they would be willing to cut back in a severe drought.

"We need to take in all the feedback that we've been getting, and say, 'Here's the problem and what are we collectively going to do about it?' " Bryant said.

\section{FAR-REACHING IMPACT}

The city and Soquel Creek Water District collectively have spent nearly $\$ 15$ million studying desalination -including $\$ 1.6$ million on the environmental report alone -- as a fix to the district's over-pumped aquifers and the city's drought problem, one exacerbated by mandated cutbacks in river and stream diversions for fish habitat. The two agencies serve about 135,000 people combined. 
http://wnww.santacruzsentinel.com/santacruz/ci_23896259/santa-cruz-puts-brakes-desal-project\#

Kim Adamson, general manager of the Soquel Creek district, said Monday, "It's really important the city continue to reach out on this issue with their citizens. We are very much in support of that."

However, Adamson said the district intends to continue pursuing desal and must consider, as alternatives, when to enact 35 percent rationing or a moratorium on new hookups.

The cost of the project has been estimated at $\$ 129$ million, a figure that includes spending that dates back to 2005 when the council identified desal as a preferred water supply fix. Opposition came largely from a few desal watchdogs until May, when the environmental report's identification of possible pump station sites on the Westside galvanized concern.

Forty-year resident Gary Miles, professor emeritus of history and classics at UC Santa Cruz, became a critic after learning a pump station could go in behind his home. He has since raised questions about the true impacts of city growth plans and fish protection on the water supply.

"It would probably be better that they put it away for good," Miles said Monday. "But before we consider this sort of option again, we have to make a really solid good-faith effort to see what we can do with the alternatives."

\section{WHAT'S NEXT}

Bernal said the city will complete the environmental report, which involves answering questions from regulators and the public, before recommending the council certify a final draft sometime in 2014 . He said it's unclear how much the additional six to 12 months of work by staff or a consultant will cost, but it will require financial approval from the council.

Certification of the report does not mean a project will be pursued. That would require separate action by the council and district board.

In November 2012, 72 percent of Santa Cruz voters passed a citizen-driven measure requiring a popular vote before the city could build the project. The district also has expressed an intent to ask customers to weigh in.

Bryant said pulling the plug on a 2014 vote is not designed to keep desal from being a divisive issue during the November 2014 council race. Bryant and Councilman David Terrazas, a former desal task force member, are eligible for re-election, but neither has signaled their intentions.

"That is the point to me," Bryant said, "that there are so many people willing to talk about this issue and that it is less about the election and more about how we get the community mobilized."

Follow Sentinel reporter J.M. Brown at Twitter.com/jmbrownreports 


\section{Appendix L: SWC Meeting Notes, 5-19-14}

\section{SWC Meeting Notes}

\section{5-19-14}

- Board Members present: Matt Orbach, Mike Rotkin, Tom Manheim, Trink Praxel, and Bill Tysseling

- SWC bylaws were ratified by a unanimous vote

- Secretary Praxel signed the "Resolution to Ratify Bylaws of the Sustainable Water Coalition"

- Secretary Trink Praxel expressed her desire to step down as Secretary of SWC

- Matt Orbach expressed his desire to take over the Secretary position

- Mike made a motion to replace Trink with Matt as Secretary of SWC and the motion passed unanimously

- Matt Orbach is the new Secretary of SWC

- Matt informed the group that we need to select a Treasurer in order to submit the SWC Statement of Information form with the Secretary of State

- Bill nominated Tom Manheim to be Treasurer of SWC and the motion passed unanimously

- Tom Manheim is the new Treasurer of SWC

- The group discussed logo options and settled on two options:

- Bill is going to talk to a graphic artist he knows and has worked with to see if she is interested, and 
- Matt pitched the idea of crowdsourcing the SWC logo through 99 Designs (presentation attached), and the group decided to go with that as a backup option if Bill's artist isn't interested

- Bill also brought up the possibility of working with a group like Yellow Bus, Vaughn Marking, or Vertical Rail to put together a more comprehensive advertising/marketing campaign

- The group discussed the contents of the first official SWC Newsletter. Ideas included:

- A short summary of the first WSAC meeting

- Links to articles of interest both locally and from around the state

- An introduction to who the SWC is and what we are trying to do

- Examples of successful desalination use worldwide

- Links to local water conservation information (City and District websites)

- A status report on local and state water supplies

- Conversations with, or testimonials from, specific groups of residents who are concerned about water

- Tom will edit the newsletter that Matt puts together before he sends it out

- Bill provided information about funding options, which included:

- An upcoming ballot item regarding the transportation commission and a $1 / 2$ cent sales tax 
- The possibility of teaming up with the transportation people because we share similar proponents and opponents

- The need to create a PAC to raise funds for both in order to raise between $\$ 200,000-500,000$ in order to run successful campaigns

- Funding would come from businesses signing up on a subscription basis with monthly contributions

- The meeting ended with Mike speaking about his impressions of the WSAC, including:

- 10 people were willing to pass a recommendation (including Rick Longinotti), but 3 stopped it at the very end mainly due to time constraints

- 10 votes are required for any affirmative action of the group because it is a consensus group

- The WSAC will pass over issues twice

- There will most likely be a trial period for Stratus Consulting

- The Water Department put their foot down about using Gary Fiske \& Associates: they will be involved

- What would make the proposal palatable to the 3 who weren't on board with the recommendation?

- Remaining potential conservation amount is still the most divisive topic

- The next WSAC meeting will be on Thursday, May 29th 
- Universal impression (among committee members) that the group needs to come to a consensus

- The idea that we (SWC and people who share our beliefs and goals) are up against an ideology

- The idea that, despite our water crisis, our society needs to stop any and all increase in energy use and reduce all consumption, no matter what the economic, social, or environmental costs

- Up next for WSAC: a crash course on water in SC that will involve a steep learning curve for many committee members

- Establishing the water shortage number will be a big battle and a really important milestone 
